\title{
Contra la Transición «pelele»: La Familia Lavapiés como síntoma con- tracultural de la izquierda radical ${ }^{1}$
}

\author{
Jaime Vindel Gamonal²
}

Recibido: 26 de febrero de 2017 / Aceptado: 8 de abril de 2017

Resumen. El artículo analiza la trayectoria del colectivo artístico La Familia Lavapiés (LFL) a partir de acervos documentales que, como el Archivo Darío Corbeira (ADC), siguen siendo sumamente desconocidos. Las actividades del grupo se ubican en el contexto de emergencia histórica de las organizaciones de la izquierda radical durante la última etapa del franquismo. En particular, LFL se encontraba vinculada a la Unión Popular de Artistas (UPA), integrada a su vez en el Frente Revolucionario Antifascista y Patriótico (FRAP), de tendencia maoísta.

Palabras clave: cultura popular; izquierda radical; contracultura; Transición; maoísmo.

\section{[en] Against the "Wimp" Transition: La Familia Lavapiés as Counter-Cultural Symptom of the Radical Left}

\begin{abstract}
The article analyzes the trajectory of the artistic group La Familia Lavapiés (LFL), taking into account documentary collections as Dario Corbeira's Archive (ADC), that remain highly unknown. The group's activities are located in the context of historical emergence of the radical left during the last stage of Franco dictatorship. In particular, LFL was linked to the People's Union of Artists (UPA), integrated in the maoist organization Revolutionary Antifascist Patriotic Front (FRAP).

Keywords: Popular Culture; Radical Left; Counter-Cultural; Transition; Maoism.
\end{abstract}

Sumario. 1. Introducción. 2. Del PCE (m-l) a la UPA: antiimperialismo y anticolonialismo entre la Guerra Civil y la Guerra Fria. 3. Viento del pueblo: la UPA como retorno cultural de lo popular. 4. LFL: contracultura entre el esplendor y el ocaso de la izquierda radical. 5. La disputa por la memoria y el territorio. 6. Final de partida .

Cómo citar: Vindel Gamonal, J. (2017): Contra la Transición «pelele»: La Familia Lavapiés como síntoma contracultural de la izquierda radical, en Anales de Historia del Arte 27, 203-231.

\footnotetext{
$1 \quad$ Este trabajo ha sido realizado como parte de los proyectos de investigación en los que participa el autor: "Visualidades críticas: reescritura de las narrativas a través de las imágenes" (HAR2013-43016-P, Ministerio de Economía y Competitividad del Gobierno de España) y "Modernidade(s) descentralizada(s): arte, política y contracultura en el eje trasatlántico durante la Guerra Fría” (HAR2014-53834-P, Ministerio de Economía y Competitividad del Gobierno de España). Agradezco las entrevistas y la atención que me concedieron Félix de la Torre Fajardo, Paco Gámez, Jesús Marchante y, ante todo, Darío Corbeira.

2 Universidad Complutense de Madrid. Facultad de Bellas Artes. Sección departamental de Historia del Arte III (contemporáneo). Investigador del programa Ayudas a la formación posdoctoral 2013 (MICINN).

E-mail: vindel.jaime@gmail.com
} 


\section{Introducción}

El lugar residual que la actividad de La Familia Lavapiés (LFL) ocupa en los relatos historiográficos aparecidos en el Estado español durante las últimas décadas es síntoma del olvido instalado sobre la memoria de aquellas experiencias políticas y artísticas que, durante el tardofranquismo y la Transición, no se ajustaron ya fuera a la consagración oficial de las bondades de lo actuado en ese período por la clase política, ya a las categorías estéticas que, desde la crítica de arte del período, definieron los parámetros teóricos del arte avanzado. Lo que permanece excluido e invisibilizado en ambos campos es la matriz popular de la historia y la cultura que atravesó los agenciamientos políticos y artísticos de los años setenta. No es este el lugar para reflexionar acerca del modo en que esa represión historiográfica de lo popular ayuda a explicar su retorno actual bajo la forma del populismo, pero volver sobre el itinerario artístico-político de LFL durante los años 1975 y 1976 puede ayudarnos a arrojar sobre el presente fragmentos de un tiempo pasado que, en su carácter contradictorio, aún aguardan su inteligibilidad histórica.

Las acciones del colectivo madrileño han sido parcialmente recuperadas por proyectos de investigación centrados en las relaciones entre arte, activismo, política y sociedad desde la Transición hasta nuestros días. Desacuerdos es, en este campo, el espacio editorial que tal vez haya alcanzado una mayor resonancia ${ }^{3}$. Sin embargo, el carácter fragmentario de esas aproximaciones, unido a una voluntad a menudo más orientada a combatir las interpretaciones del arte español tras el proceso de normalización democrática que a diagramar la inscripción histórico-política de esas experiencias, dificultan rescatar su singularidad. En el caso de LFL, el sentido de su corta existencia resta un tanto opaco en la medida en que aún no son conocidas algunas de sus intervenciones más relevantes, mientras que las que sí han sido revisadas no acaban de componer una imagen más precisa de los resortes ideológicos y relacionales que las propiciaron.

La marginalidad historiográfica de LFL también se debe a que ocupó el margen izquierdo de la cultura de resistencia del tardofranquismo: su vinculación con la Unión Popular de Artistas (UPA), el Frente Revolucionario Antifascista y Patriótico (FRAP) y el Partido Comunista de España (marxista-leninista) (PCE (m-1)), organizaciones de tendencia maoísta, situaba al colectivo en una posición de disenso respecto a la línea hegemónica del Partido Comunista de España (PCE), cuya progresiva inclinación a adoptar las tesis del eurocomunismo conduciría al principal partido de la izquierda española a abandonar el esquema leninista en la concepción del cambio histórico ${ }^{4}$. Desde una posición subalterna que se oponía frontalmente a cualquier pacto con las elites del franquismo, el activismo gráfico de la UPA, las viñetas del colectivo El Cubri ${ }^{5}$ o las intervenciones de LFL evidenciaron en el contexto

Otro ejemplo destacado es el volumen publicado por la editorial Brumaria titulado Arte y transición, donde Darío Corbeira narra en clave autobiográfica su experiencia como integrante de LFL, cf. D. Corbeira, "Arte y militancia en (la) transición", J. Albarrán (ed.), Arte y transición, Brumaria, 24, pp. 71-103.

4 Cf. J. Andrade Blanco, El PCE y el PSOE en (la) transición: la evolución ideológica de la izquierda durante el proceso de cambio político. Madrid, Siglo XXI, 2012.

5 El colectivo de viñetistas El Cubri fue creado en 1973 por Saturio Alonso y Felipe Hernández Cava, a los que un año más tarde se sumaría Pedro Arjona. El colectivo tuvo su sede en el barrio de la Elipa e inició sus actividades con la elaboración de una serie de viñetas para la UPA. La vinculación orgánica con el FRAP de Alonso y Arjona no impidió que el grupo trabajara para otras organizaciones políticas. La estética de El Cubri, además de inscribirse en los conflictos políticos del presente, se sedimentó en la creación de una contraimagen 
de crisis del régimen una resistencia a las consecuencias sociales y políticas que avizoraban en una Transición pactada. Si en su momento de eclosión esa disidencia irradiaba lucidez, radicalismo, heterodoxia y anacronismo a partes iguales, hoy, en un período en que los consensos de la Transición son objeto de revisión crítica, cobra la categoría de rareza premonitoria. La temprana denuncia que establecen los textos producidos en el entorno de la UPA respecto al papel que iba a cumplir el monarca Juan Carlos I como figura "pelele" de una transición lampedusiana, basada en la reconversión de los intereses de las oligarquías del franquismo a la apariencia democrática, es una buena muestra de ello.

Pero esa marginalidad puede explicarse también por el hecho de que las actividades de LFL no se ajustan a la tonalidad política de los parámetros conceptuales con los que la crítica y la historia de arte delimitaron el territorio estético de los denominados "nuevos comportamientos artísticos". El énfasis de intelectuales vinculados al PCE como Simón Marchán Fiz al defender la autonomía relativa de la obra de arte se inscribía en una tradición que las prácticas de LFL ponían en cuestión. En ellas, el deseo de combinar la apertura hacia lo social y la experimentación vanguardista no siempre se preocupaba de resguardar la especificidad lingüística de la obra de arte. Lo que esas experiencias demandan, en este plano, es una aproximación a su memoria material que no reduzca su legibilidad vanguardista a una valoración ante todo fenomenológica; que, incluso en su carácter fallido o meramente intencional, ponga el acento en otros aspectos como la redefinición del lugar del artista en las movilizaciones populares, la apertura del arte a nuevos públicos, la generación de nuevas estructuras, alianzas y formas organizativas o la visibilización de conflictos que no formaban parte de la agenda predominante en la izquierda social y política del momento ${ }^{6}$. Por decirlo en otros términos, en casos como LFL puede resultar más revelador aproximarse a sus acciones al contrastarlas con el legado (tan radical como problemático) de las vanguardias políticas del siglo XX que desde ciertos lugares comunes en la interpretación de las vanguardias artísticas de ese período. La fugaz trayectoria del grupo se encuentra en numerosos aspectos más próxima a la matriz de sentido que guió en América Latina, luego de la Revolución Cubana, los debates de artistas e intelectuales en torno a la necesidad de articular la actividad de las vanguardias artísticas y las organizaciones populares que al esquema categorial que ha regido en la historiografía y la crítica de arte españolas la valoración de los conceptualismos nacionales.

En ese campo de tensiones, LFL alumbró un ámbito de creación visual y acción política no sometido a ninguna de las tres lógicas coactivas que pesaban sobre sus integrantes: la represión franquista sobre los cuerpos y las subjetividades (monopolios estatales de la violencia y la moral), la hegemonía contracultural del PCE y los

gráfica de la historia de la dictadura franquista en el momento de declive del régimen. Esta ambición encontró su expresión más sistemática en la serie de Francografías que El Cubri ideó en 1977 como portadas de los fascículos de la Historia del franquismo publicada por la editorial Sedmay y escrita por Bernardo Díaz Nosty y Daniel Sueiro. Cf. El Cubri, Tal como éramos. Valencia, Edicions de Ponent, 2008 y El Cubri, Francografias. Valencia, Edicions de Ponent, 2006.

6 Esta comprensión crítica de LFL se encuentra emparentada con el materialismo cultural de Raymond Williams y su conceptualización del arte en términos de estructura y organización de la experiencia. Para el sociólogo británico, la capacidad de construir vínculos colectivos aparecería como una forma creativa de la cultura de las clases trabajadoras desde la emergencia del industrialismo. Un análisis excelente de la obra de este autor se encuentra en M. E. Cevasco, Para leer a Raymond Williams. Buenos Aires, Universidad Nacional de Quilmes, 2003. 
dictámenes del PCE (m-l) y el FRAP en torno a la regulación de la vida política, social y afectiva de sus militantes. Los sinsabores de la militancia, sumados a la invisibilización historiográfica y a la demonización mediática de la izquierda radical, explican, al menos en parte, que algunos de sus protagonistas no siempre reconozcan su paso por esas organizaciones. En este sentido, cabe interpretar los entornos de socialización e intervención generados alrededor de la UPA (que, además de LFL, incluían a integrantes de grupos de teatro experimental como Tábano y de viñetistas como El Cubri) como un conflictivo magma atravesado por esas tres esferas, que con el transcurso del tiempo contribuyó a constituir un territorio común de vida en el que confluían militantes de otras organizaciones de la izquierda. La acción colectiva en el espacio público diluía con frecuencia la autoría de la UPA o de los subgrupos a ella asociados.

\section{Del PCE (m-l) a la UPA: antiimperialismo y anticolonialismo entre la Guerra Civil y la Guerra Fría}

Resulta difícil comprender las acciones e instalaciones de LFL sin valorar su inscripción en las coordenadas ideológicas que el PCE (m-1), el FRAP y la UPA manejaron en su lectura geopolítica del contexto internacional de la Guerra Fría. El anticolonialismo auspiciado por estas organizaciones se articulaba al menos en torno a tres vectores-fuerza precisos: 1) En el plano histórico nacional, el deseo de actualizar la contienda guerracivilista mediante la reactivación de la lucha inspirada en el frentismo popular de los años treinta. Este aspecto implicaba de por sí una revisión crítica de lo actuado por la izquierda comunista durante la Segunda República y la Guerra Civil $^{7}$. 2) El segundo vórtice se relacionaba con los disensos en el movimiento comunista internacional. El triunfo de la revolución maoísta en China y la posterior ruptura con la URSS ofrecían a ese movimiento una reconfiguración del mapa político de la Guerra Fría que cuestionaba la bipolaridad Este-Oeste e introducía la necesidad de repensar la especificidad de las insurrecciones revolucionarias desde las asimetrías Norte-Sur entre países desarrollados y subdesarrollados. 3) En tercer lugar, el fenómeno de los no alineados se vinculaba con las luchas de liberación nacional que se habían desplegado durante la Guerra Fría en diversas geografías del globo, desde el Lejano oriente (con Vietnam como polo aglutinante del anti-imperialismo del período) y África hasta el ciclo de sublevaciones abierto en América Latina por la Revolución cubana de 1959. Aunque el paralelismo entre el carácter semicolonial de España y el colonialismo que afectaba a esas regiones del mundo fuera, con frecuencia, una comparación de brocha gorda, esta se constituía en una lanzadera subjetiva para la consecución de aquella independencia nacional que revirtiera la reconversión neocolonial del régimen "yanqui-franquista" desde los pactos de 1953.

En cuanto a la política frentepopulista, la guerra popular revolucionaria que el PCE (m-l) ambicionaba detonar hundía sus raíces históricas en la crítica radical del papel jugado por el PCE durante la Guerra Civil. En un documento de circulación interna titulado "Historia de España: la guerra nacional contra el fascismo", se acusaba

Sobre la relación de "continuidad" entre la política frentepopulista de los años treinta y la emergencia del FRAP, cf. C. Laiz, La lucha final. Los partidos de la izquierda radical durante la transición española. Madrid, Libros de la Catarata, 1995, pp. 155 y ss. 
a Santiago Carrillo de repetir los errores cometidos por el PCE durante su participación en el gobierno republicano al poner la acción del partido a "remolque" de los intereses de la burguesía. Frente a esa tendencia conciliadora, la creación del FRAP respondía a la convicción de "que ha de ser la clase obrera aliada con el campesino pobre (...) la que dirija la fase actual de la revolución nacional esforzándose por unir y movilizar en un frente revolucionario a todas las fuerzas antiimperialistas" . Ante la inexistencia de un "análisis crítico" en las filas del revisionismo carrillista, el PCE (m-1), sin dejar de reconocer el papel heroico y abnegado del PCE durante la guerra, subrayaba también desde la elevada atalaya de los setenta los "errores políticos y militares, estratégicos y tácticos" que habían conducido a la derrota del bando republicano".

Instalados en esa distancia crítica, se insistía en que la guerra no había concluido con la victoria del bando nacional, ya que tras tres décadas de franquismo sus rescoldos aún seguían vivos ${ }^{10}$. Las mutaciones que el régimen había experimentado a lo largo del tiempo en su fachada política y en su modelo productivo no debían inducir al error de pensar que la composición social de la estructura de poder había variado. Esta seguía respondiendo a los intereses de la oligarquía financiera y los terratenientes agrarios, sostenidos por el clero y el ejército. El acento maniqueo en la revisión dogmática del pasado hacía que las posiciones políticas defendidas por la organización fueran más deudoras de un ajuste de cuentas con la historia que operativas a la hora de enfrentar las condiciones objetivas y subjetivas de la sociedad española tardofranquista. La "guerra de movimientos" que supuestamente debería haber desplegado el Ejército Popular durante la contienda civil aparecía como una receta anacrónica en un contexto donde la lucha de clases había adquirido componentes diferentes, que se precipitarían en la vertiginosa acumulación de huelgas que iban a marcar el final del franquismo y los inicios de la Transición. En disonancia tanto con la cultura pactista de la que se acusaba al PCE como con la emergencia de novedosas formas de autonomía obrera ajenas al verticalismo del sindicalismo clásico, el "frente único patriota" que el FRAP deseaba impulsar aparecía como una opción anclada en imaginarios políticos del antagonismo deudores de otros tiempos y geografías ${ }^{11}$.

La emergencia del PCE (m-l) primero y del FRAP después han de entenderse en el contexto de las tensiones internas al campo comunista durante el transcurso de la Guerra Fría. Tras las revelaciones del XX Congreso del PCUS (1956) sobre los crímenes de Stalin y el giro de la política de Brezhnev hacia la "coexistencia pacífica" con el imperialismo estadounidense, la China maoísta se convertirá para el comunismo occidental en un peculiar referente, cuya atracción abarcaba desde su capacidad

"Historia de España: la guerra nacional contra el fascismo", s. f., s. f., p. 1. Archivo Darío Corbeira (ADC).

$9 \quad$ Esos errores se sintetizaban en los siguientes puntos: "1. Errores en la Política de Alianzas (con relación a la Política del Frente Popular). 2. Vacilaciones en la política de participación en el aparato estatal (el P[artido] tuvo falta de decisión para asumir su papel). 3. Errores en la Política militar (con relación a las fuerzas armadas, a la táctica y a la estrategia). 4. Contemporización con las democracias occidentales". Ibid., p. 5.

10 Este aspecto ha sido subrayado también por Ana Domínguez Rama: "De todos los grupos que actuaron durante el franquismo puede decirse que sólo el FRAP, con pretensiones de expansión estatal, llegaría a desplegar acciones de «guerrilla urbana» asociadas al universo político de la Guerra Civil, es decir, influenciado por el recuerdo histórico de la contienda y con intenciones de establecer lazos de continuidad con la lucha antifascista de los conflictivos años treinta". A. Domínguez Rama, "La «violencia revolucionaria» del FRAP durante el tardofranquismo", en: C. Navajas Zubeldía y D. Iturriaga Barco (eds.), Novísima. II Congreso Internacional de Historia de Nuestro Tiempo. Logroño, Universidad de la Rioja, 2010, p. 401.

11 Consuelo Laíz relacionó esta inadecuación con la fundación de la organización en la cultura del exilio, cf. C. Laíz, La lucha final. Los partidos de la izquierda radical durante la transición española. op. cit., p 158. 
para preservar las esencias de la herencia estalinista a su potencia de inspiración teórica, cuando de lo que se trataba era de cuestionar los restos eurocéntricos en la comprensión marxista del desenvolvimiento histórico. La parálisis del antagonismo detectada en la inercia de la política soviética postestaliniana se acentuaba en el caso español por la política de "reconciliación nacional" amparada por la dirección del PCE. Ambos elementos contribuirán a la escisión de un grupo de militantes de la organización en 1964, quienes conformarían el PCE (m-1), liderado por Raúl Marco y Elena Odena ${ }^{12}$. Tras una primera fase de consolidación, la organización alcanzaría un cierto impulso en el intervalo entre las décadas de los sesenta y los setenta, haciendo suya, en primer lugar, la crítica a cualquier alternativa pacífica de construcción del socialismo planteada por el Partido Comunista Chino (PCCh) y, con posterioridad, las tesis del comunismo albanés. La consigna maoísta según la cual la guerra imperialista debía ser respondida mediante la guerra civil prolongada sería trasladada por el PCE (m-1) a su interpretación revolucionaria del tardofranquismo ${ }^{13}$.

En relación a América Latina, el ciclo de luchas antiimperialistas y de liberación nacional se cerró de manera abrupta con el golpe de Estado que acabó con el gobierno de la Unidad Popular chilena. En la documentación de época se puede constatar que este acontecimiento fue uno de los elementos que impulsaron al FRAP a dar el paso hacia la lucha armada. El Comité pro-FRAP se había formado apenas un par de años antes (enero de 1971) en París y pretendía aglutinar a crecientes sectores de la cultura política de la izquierdas con el objetivo de abrir una vía de ruptura frente al tacticismo estadista del $\mathrm{PCE}^{14}$. Al destacar los límites de una acción de gobierno sitiada por los poderes fácticos y boicoteada por el bloqueo parlamentario ejercido por la oposición chilena, un documento interno deslizaba sobre las posiciones sostenidas por el presidente Allende las habituales acusaciones de reformismo y revisionismo, que de manera indirecta salpicaban la estrategia adoptaba en el ámbito nacional por el PCE. La vulgata del dogmatismo leninista identificaba el problema político central con la toma del poder, distinguiendo entre hacerlo de derecho y de hecho ${ }^{15}$. La decisión de Allende de no armar al pueblo era subrayada como el principal de los errores de la vía chilena al socialismo, un aspecto que no podía ser obviado a la hora de pensar las movilizaciones populares contra el franquismo.

12 Además del PCE $(\mathrm{m}-1)$, durante esa misma época surgirían también otras organizaciones que se reclamarían como las auténticas herederas del marxismo-leninismo. Entre ellas figuran el Grupo Unidad, posterior Partido Comunista de España (internacional) PCE (i) o la Organización de Marxistas Leninistas Españoles (OMLE).

13 Sin embargo, esta distancia respecto a la dirección del PCE no implicaba en la práctica desdeñar la colaboración con las bases de ese partido, que con frecuencia compartían los objetivos revolucionarios de las organizaciones de la izquierda radical. Como ha señalado Ana Domínguez Rama, "durante todo el tardofranquismo su actuación de cara a la concienciación política de la clase obrera y a la radicalización de los conflictos, al lado muchas veces de la militancia del PCE y del PSUC [Partido Socialista Unificado de Cataluña], contribuyó a la extensión de los movimientos sociales de oposición y a la agudización de la conflictividad político-social que caracterizaron el quinquenio final de vida de la dictadura", A. Domínguez Rama, "La «violencia revolucionaria» del FRAP durante el tardofranquismo", op. cit., p. 397.

14 El Comité Coordinador pro-FRAP se constituyó en la casa que Arthur Miller había dejado al ex-socialista y presidente honorífico de la organización Julio Álvarez del Vayo, quien había cumplido un papel destacado en la organización del exilio republicano en América Latina tras concluir la Guerra Civil, cf. Equipo Adelvec, FRAP. 27 de septiembre de 1975. Madrid, Vanguardia Obrera, 1985, pp. 26-27.

15 "Desde el punto de vista político, la pomposamente llamada «vía chilena al socialismo» ha fracasado y, con ella, todas las esperanzas reformistas del revisionismo actual. En un proceso político, el problema central es la toma del Poder. Se puede llegar al mismo a través de unas elecciones parlamentarias, allí donde se dé una República democrática burguesa, pero una cosa es tener el Poder de derecho y otra de hecho. Este ha sido el caso de Chile con su Unión [sic] Popular (U. P.)", s. t., s. f., p. 1. ADC. 
Ello no impedía, sin embargo, que el recuerdo de la lucha del pueblo chileno fuera recuperado por la UPA a través de la evocación heroica de Víctor Jara. El cantautor habría abierto, junto a otras manifestaciones plásticas como las brigadas muralistas, sendas a ser exploradas en otros contextos geopolíticos con el objetivo de conformar "un verdadero arte popular"16. Los debates artísticos sostenidos en los entornos de la UPA tendían un invisible hilo transatlántico con los protagonizados por diversos creadores latinoamericanos en el tránsito entre las décadas de los sesenta y los setenta. Una muestra de ello fueron las discusiones que se produjeron en los encuentros de artistas e intelectuales que se celebraron en La Habana y Santiago de Chile durante ese período ${ }^{17}$. Como un síntoma de época, un rasgo común parece atravesar todos esos posicionamientos. Cuando las concepciones de la cultura popular que proyectaban los procesos revolucionarios en curso conseguían desacoplarse de los referentes del pasado, su formulación futura solía adoptar ante todo una forma negativa, esto es, en primer lugar se especificaba lo que no debía ser. Ni la vanguardia imperialista, ni el folclore tradicional, ni el realismo naturalista parecían referentes válidos para un arte popular que con frecuencia acababa por identificarse con la propia praxis política. Si el artista argentino Luis Felipe Noé proclamó la revolución como el arte de América Latina, los documentos anónimos de la UPA, evocando nuevamente la figura de Jara, reivindicaban "el artista consciente de que su verdadera función intelectual estriba exclusivamente en (...) demostrar las relaciones sociales colectivas e individuales del presente histórico que le ha tocado vivir y, al mismo tiempo, tratar de ejercer un papel transformador de la realidad"18. Los modos en que se concretarían ambas pretensiones no eran definidos ${ }^{19}$.

Un espaldarazo adicional a las posiciones rupturistas del PCE (m-l), el FRAP y la UPA lo otorgó la deriva de la situación política de Portugal tras la Revolución de los Claveles de 1974. Lejos de consolidar las tesis reformistas de Carrillo, el país vecino parecía evidenciar los límites de todo acuerdo transicional que no supusiera una ruptura radical con la democracia burguesa. Esta denuncia trataba de evitar a toda costa el transformismo político del régimen franquista, destinado a "adormecer" las (siempre presupuestas) ansias revolucionarias del pueblo ${ }^{20}$. La deriva eurocomunista que acabaría propugnando la dirección del PCE, en paralelo a su progresivo aleja-

16 Documento s.t. y s.f., p. 2. ADC. El documento incluía una cita del libro publicado en 1968 por la editorial Ciencia Nueva bajo el título Sobre arte y literatura, prologado por Valeriano Bozal, que recopilaba diversos textos de Marx y Engels sobre esas materias.

17 Cf. G. Carnevale, M. Expósito, A. Mesquita y J. Vindel, Desinventario: esquirlas de Tucumán Arde en el Archivo Graciela Carnevale. Santiago de Chile, Ocholibros, 2015. pp. 173-238.

18 Documento s.t. y s.f., p. 2. ADC.

19 Un año después de la disolución de LFL, Darío Corbeira participaría en dos muestras de homenaje al expresidente chileno organizadas por el Museo Internacional de la Resistencia Salvador Allende. La primera, inaugurada el 12 de septiembre de 1977, tuvo lugar en las siguientes galerías de Madrid: Multitud, Juana Mordó, Rayuela, El Coleccionista y Aele. La segunda, con sede en el Mercado Central de Zaragoza, se presentó el 25 de noviembre del mismo año. Las exposiciones, que incluían una amplia nómina de artistas nacionales y la presencia de referentes plásticos de la escena latinoamericana como Nemesio Antúnez o Ricardo Carpani, recuperaba en su folleto el discurso pronunciado por Allende en 1972 con motivo de la inauguración del Museo de la Solidaridad, que se pensaba instalar en el edificio de la UNCTAD III, todo un símbolo de la Unidad Popular. A las palabras de Allende se sumaban también las del crítico brasileño Mario Pedrosa, quien agradecía el compromiso y la solidaridad de "los artistas libres de España", y las de José María Moreno Galván, que no dudaba en declararse enemigo de los "momios", el apelativo popular empleado en Chile para denominar a la derecha conservadora que saboteó el gobierno de Allende y apoyó más tarde el golpe y la dictadura de Pinochet.

20 Cf. Julio Calafat, pseudónimo de Raúl Marco, "Sobre los acontecimientos de Portugal”, artículo aparecido en Revolución Española ( $\mathrm{n}^{\circ} 7$ de junio de 1974) y reproducido por la Secretaría de Agitación y Propaganda del Comité de Madrid del PCE (m-1) en julio de 1974, p. 3. ADC. 
miento de la URSS, debía ser contestada por una firme reivindicación del leninismo; la consigna de la huelga popular pacífica, entendida como la apertura de una nueva etapa de negociación política en la cual la oligarquía no renunciaría a preservar sus intereses de clase, suplantada por el llamado a la huelga revolucionaria concebida como disparador de una guerra popular prolongada. En el análisis comparativo de coyuntura se subrayaba certeramente que, a diferencia del escenario portugués, en España no existía ninguna posibilidad de que el Ejército se sumara a un proceso revolucionario, por lo cual era necesario depositar todas las esperanzas en la combatividad social de la clase obrera y el campesinado pobre. La democracia popular debía adoptar la forma de una república federal que reconociera las distintas nacionalidades que componen el Estado español y su derecho de autodeterminación ${ }^{21}$, de modo que las tesis expuestas en torno a la relación entre España y sus colonias afectara a la composición interna del territorio y las identidades del Estado.

\section{Viento del pueblo: la UPA como retorno cultural de lo popular}

LFL formaba parte de la UPA, una organización del FRAP que aglutinaba al sector cultural del PCE (m-1). Surgida también en el exilio parisino, la actividad de la UPA pasa por ser, debido en buena medida al carácter clandestino de la experiencia, uno de los hitos de las articulaciones entre política radical, activismo urbano y práctica artística más desconocidos de la época tardofranquista. La vinculación que la UPA mantenía con el FRAP, algunos de cuyos militantes fueron víctimas de las últimas ejecuciones de la dictadura, y el PCE (m-1), ha ocultado bajo la sombra de la violencia revolucionaria la memoria de una militancia tan viva como llena de contradicciones. La línea ideológica de la UPA destacaba por su crítica anticolonial y por el carácter internacionalista (con especial énfasis en los vínculos con el contexto latinoamericano) de su resistencia al imperialismo cultural. En todo caso, resaltar este origen en el exilio de la organización no debe hacernos olvidar los núcleos preexistentes en el Estado español que nutrieron con posterioridad la UPA, como la Federación Universitaria Democrática Española (FUDE), que cumplió un papel activo en el ciclo de protestas que el movimiento estudiantil impulsó desde 1969.

La UPA se dividía en diversas secciones, que respondían a las diferentes expresiones artísticas: Pintura, Cine, Música, Teatro, Literatura. Esas secciones eran coordinadas por un comité integrado por representantes de cada una de las áreas y un miembro de la revista Viento del Pueblo, el órgano de expresión de la organización. Entre las principales funciones de la UPA figuraba el aproximar a los diversos creadores a los entornos de agitación y militancia del FRAP. Una de las actividades del Comité de Artistas Plásticos consistía en hacer visitas a los profesionales del sector para vender el último número de la revista, lo que les permitía obtener magros fondos para cubrir gastos como los implicados en la impresión de propaganda. La escasez de militantes inmersos en la actividad cotidiana de la organización hacía necesario incrementar su número de manera acelerada. Esta tarea se veía dificultada por su marginalidad respecto al mundo profesional de la cultura, que hacía que pasaran como absolutos desconocidos cuando trataban de establecer esos vínculos. El fracaso en este flanco no pudo ser más notorio. Sin embargo, esa aproximación al

${ }^{21}$ Cf. “Acerca del problema de las nacionalidades", documento interno, 17 pp. ADC. 
sector facilitó la celebración de exposiciones en ateneos del extrarradio madrileño como los de Vallecas y de Pegaso ${ }^{22}$. En paralelo a la organización de esas muestras se elaboraron pequeños textos que ya anticipaban la orientación de LFL. En ellos se apuntaba la necesidad de desbordar la presencia de las prácticas artísticas hacia nuevos espacios de sociabilidad. Se trataba de recuperar una tradición del arte popular que se remontaba a la Segunda República. El impulso de las misiones pedagógicas debía revitalizarse en los entornos periféricos de la gran ciudad, así como en una España rural y campesina lavada por la retórica maoísta.

La mejor fuente documental para rastrear los debates en torno a las relaciones entre las prácticas artísticas y la política revolucionaria en el seno de la UPA son los sucesivos números de Viento del Pueblo, cuyo título remitía al poemario que Miguel Hernández publicara en 1937 durante la Guerra Civil. La revista es una guía de acceso a los presupuestos ideológicos que guiaron las discusiones al interior de la organización. En ellas, la crítica de las dinámicas intrínsecas al mundo cultural siempre aparecía inscrita en la necesidad de confrontar políticamente la coyuntura social del tardofranquismo. Los dos primeros números de la revista aparecieron en París; los tres restantes en Madrid. Sus páginas impugnaban desde el ámbito cultural el proceso de reconversión democrática de la oligarquía franquista, en la medida en que este implicaba ignorar los intereses de las mayorías sociales. La UPA, en la línea demarcada por el PCE (m-1) y el FRAP, consideraba que no había salida posible para las aspiraciones populares en el marco de la concertación parlamentaria que vislumbraba en las posiciones pactistas del PCE, funcionales a la prolongación bajo un nuevo rostro de los intereses económicos y culturales de la burguesía franquista.

Los números sucesivos de Viento del pueblo alcanzaron en su definición formal un virtuosismo inédito entre las revistas clandestinas del antifranquismo. La diagramación gráfica de la publicación, con énfasis en el uso del color y la tipografía, muestra toda una gama de soluciones visuales a la hora de articular los contenidos de varios de sus números. En ellos se registraban los progresos en la irradiación popular de la actividad de los artistas de la UPA. El colectivo de avanzada en ese plano eran los actores, que según se reflejaba ya en el número 3 (diciembre de 1972) era "el que más y mejores experiencias tiene acumuladas" ${ }^{23}$. Aunque a la hora de enumerar los logros concretos alcanzados se subrayaban más bien objetivos de tipo profesional, como la "actualización de contratos, ensayos pagados, función única, cooperativas de actores, etc.", no dejaba de recalcarse que en el futuro inmediato el trabajo colectivo debía centrarse en los barrios madrileños, "como medio de desarrollar un teatro popular en primera línea de combate"24. A esta labor debían sumarse

22 Félix de la Torre Fajardo recordaría como anécdota sobre esta particularidad de la UPA que "no fue hasta 1974 que realizamos una exposición colectiva junto con otros pintores, cuando conocimos lo que hacíamos los propios militantes, y eso después de cuatro años de militancia”. En el mismo escrito describía del siguiente modo la rutina de la visita a otros artistas: “(...) íbamos llenos de ilusión y ardor revolucionario a las casas de los pintores que en nuestra lista estaban catalogados como «majetes». En general nos recibían muy bien. Teníamos preparado nuestro sermón (...) y casi siempre funcionaba. El momento malo es cuando por ejemplo el pintor preguntaba ¿y tú cómo te llamas?... era un lío porque claro, entre nosotros funcionábamos con nombre de guerra y eso se respetaba a unos niveles increíbles, y salíamos del apuro como podíamos (...)”. F. de la Torre Fajardo, "LFL. Una experiencia de arte popular", 1977, manuscrito, p. 6. ADC.

23 Sus integrantes tendrían un rol activo en la huelga de actores que se prolongaría entre el 4 y el 12 de febrero de 1975. La documentación conservada en el Archivo General de la Administración da cuenta del seguimiento que el Ministerio de Información y Turismo hizo de dicha huelga, en la que identificaba la mano instigadora del FRAP, aunque en realidad ninguno de los detenidos pertenecía a esta organización.

24 "Editorial", Viento del pueblo, 3, diciembre de 1972, pp. 3-4. Un artículo incluido en el mismo número y 
cantantes, músicos, grupos folclóricos e incluso aquellos cineastas que estuvieran dispuestos a romper con las formas de producción y distribución impuestas por la industria "yanqui" con el objetivo de fomentar circuitos alternativos y clandestinos "de cine amateur y grupos de barrio" 25 . En lo relativo a la plástica, el editorial de este número se hacía eco de los debates que venían sosteniendo los círculos de artistas críticos con los avejentados planes de estudio de las escuelas de bellas artes, pero sin embargo la publicación no ponía en ningún momento en cuestión la identificación simbólica del artista con la figura del pintor, un aspecto contra el que se revolvería la práctica posterior de LFL:

Los pintores continúan soportando el sistema de mercado de galerías y "merchantes" y se encuentran con una Escuela de Bellas Artes donde solo se enseña una pintura de formas y contenidos reaccionarios y en la que las movilizaciones han de ser particularmente importantes.

Asimismo, están comenzando a crearse grupos de artistas plásticos con la tarea de acercar las artes plásticas a nuestro pueblo, preparando exposiciones de contenido popular en muy diversos lugares. Igualmente se trabaja con las posibilidades expresivas del cartel y la imagen gráfica al servicio de la lucha popular ${ }^{26}$.

La gráfica política fue de hecho una de las experiencias de síntesis entre la producción visual crítica y la territorialidad militante más relevantes del frente cultural del FRAP. Los carteles se realizaban a partir de estarcidos en plantillas que se distribuían y pegaban en barrios y fábricas. Buena parte de ese imaginario se movilizó contra la restauración monárquica que, a modo de franquismo sin Franco, el PCE (m-1), el FRAP y la UPA entreveían ya entonces como la probable decantación del proceso transicional. La huelga general revolucionaria era el leitmotiv que debía aglutinar los esfuerzos de artistas e intelectuales con la intención de revivir el ímpetu insurreccional que había caracterizado la proclamación de la II República en abril de 1931. En numerosos pasajes de Viento del pueblo, la especificidad de las cuestiones que incumbían al trabajo de los artistas -ya fuera en el aspecto netamente profesional, ya como parte activa para la construcción de un bloque social revolucionarioquedaban ensombrecidos, cuando no directamente obviados, por la ritual repetición de los puntos programáticos del partido. La suspensión de los problemas estéticos se justificaba en base al carácter provisional que el arte y la cultura tenían antes de la República popular y federativa por venir. El arte debía adquirir ante todo un carácter pedagógico, cuya inspiración bebiera de fuentes tan diversas como el cine soviético, las campañas de alfabetización en la Cuba posterior a la revolución o los periódicos murales (dazibaos) de la Revolución Cultural China, "a través de los cuales cualquier persona podía ejercer la crítica y la autocrítica"27.

El proceso de producción de Viento del pueblo incluía etapas y tareas como la recopilación de materiales, las reuniones para discutir la selección de contenidos, las transcripciones y maquetación de la revista o la tirada de planchas. El diseño corrió a cargo de un equipo más reducido, donde destacó la aportación de Pedro Arjona, miembro de El Cubri. Darío Corbeira colaboró con él en la elaboración del

titulado "Impulsemos el teatro en los barrios populares" profundizaba en estas cuestiones. Ibid., p. 9.

Ibid., pp. 3-4.

Ibid., pp. 3-4.

"Por una comunicación popular", Viento del pueblo, 3, diciembre de 1972, pp. 14-16. 
concepto editorial del número 4 de la serie, probablemente el más ambicioso de los que aparecieron ${ }^{28}$. La portada, compuesta por un ejército ajedrecista de peones invertidos que amenazaba jaquear al rey con un manchón sangriento de tinta roja, se presentaba como una metáfora visual de la coyuntura histórica (octubre de 1973), cuya resolución debían dilucidar las fuerzas enfrentadas en la lucha de clases del último franquismo. La tipografía del título de la revista avanzaba soluciones formales con una apariencia visual que se ha replicado en procesos de movilización popular más recientes (Fig. 1) ${ }^{29}$. Las páginas interiores, por su parte, jugaban a modo de desplegable con los colores de la bandera republicana, que en una primera imagen emergían como trasfondo de la silueta correspondiente a una de las manifestaciones del periodo.

Los primeros apuntes del número informaban al lector de que Viento del pueblo se constituía a partir de ese momento en el "órgano de las Juntas de Artistas del

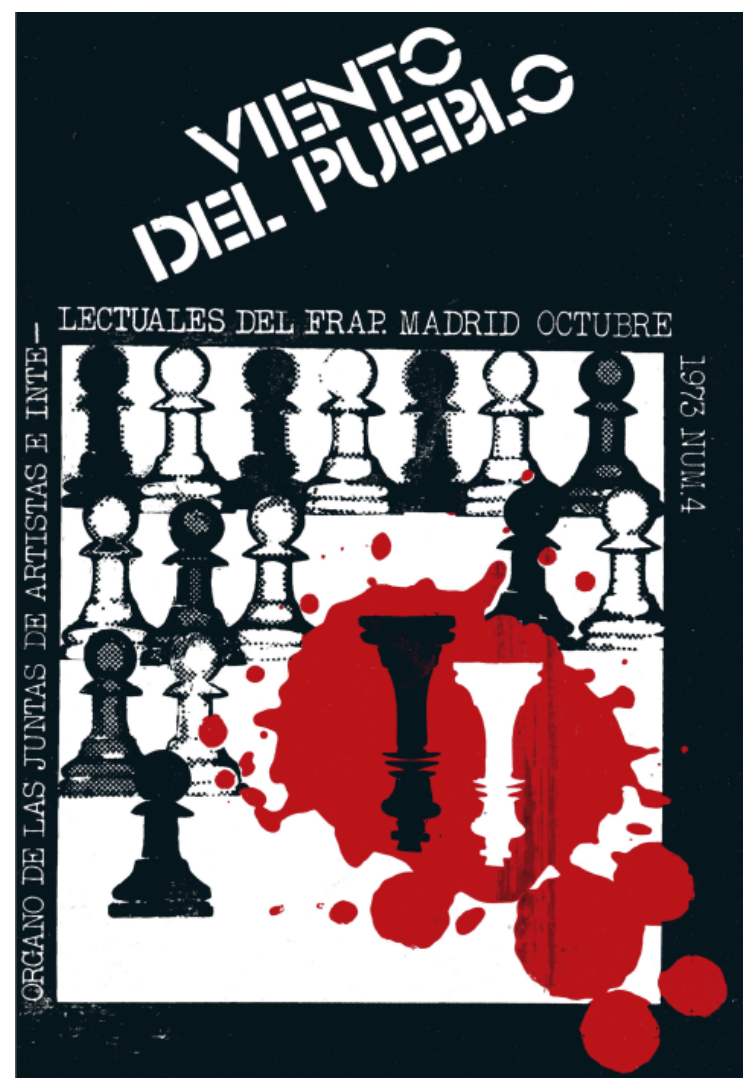

Figura 1. Portada de Viento del Pueblo, 4, octubre de 1973.

28 A Corbeira se debieron, en concreto, la idea de entintar con los colores de la bandera republicana las sucesivas páginas del número, así como la inclusión del artículo dedicado a los concursos de arte (basado en informaciones facilitadas por Dámaso Santos Amestoy) y de elementos como heliograbados o fotocopias que complementaban las imágenes serigráficas.

29 A modo de curiosidad, la tipografía era similar a la empleada por Democracia Real Ya (DRY), colectivo impulsor de la primera convocatoria del $15 \mathrm{~m}$. 
FRAP", a cuyos integrantes conminaba a concretar en la práctica "una mayor unidad popular, una mayor flexibilidad y unas condiciones más idóneas para la realización de un arte combativo, así como para nuestro propósito de ir haciendo intentos en la creación de un arte popular" 30 . Se trataba, por tanto, de superar la centralidad que las luchas sectoriales habían tenido hasta ese momento, un síntoma de la procedencia pequeño-burguesa de los artistas que los habría alejado de las masas populares a las que en última instancia debían dirigir su actividad. El látigo fustigador reasomaba en los reclamos de "reafirmar nuestra conciencia y comprender mejor por medio de una relación más directa y continua las necesidades culturales que en un momento artístico determinado tiene nuestro pueblo"31. Esa autocrítica se hacía extensible a la orientación que había tenido la propia revista, que en lugar de ser "el portavoz de las aspiraciones de los artistas" debía constituirse a partir de entonces en un órgano de expresión que aglutinara la documentación, síntesis y transformación de la realidad sobre la que debía operar el arte dialectizado.

El resto de los contenidos del número se dedicaban a asuntos como el el nombramiento de Carrero Blanco como presidente del gobierno, interpretado a modo de maniobra del régimen destinada a allanar el camino para la sucesión de Franco por Juan Carlos de Borbón en la jefatura del Estado; el cuestionamiento de la legitimidad de los concursos artísticos; la crónica del festival de artes escénicas Nancy 73; la valoración del alcance político de la "canción protesta"; la denuncia gráfica de la tortura padecida por los militantes antifranquistas y la crítica de las contradicciones del cine profesional, que pese a su carácter aparentemente popular evidenciaba serias dificultades a la hora de constituirse como un arte revolucionario. En las páginas de cierre se anunciaba también la aparición de Arte y lucha, órgano de difusión de la UPA parisina, que suplía a Viento del pueblo después de que la edición de esta publicación se desplazara a Madrid a partir del tercer número.

La audacia formal del cuarto número de Viento del pueblo sería cuestionada en la reseña editorial de la siguiente edición de la revista, donde se apostaba por conseguir para la publicación una periodicidad bimensual "aún a costa de una pérdida de calidad formal (...), secundaria frente a la actualidad y el contenido de los artículos". De esta manera se trataba de "llevar los planteamientos de un arte popular y revolucionario a la misma praxis de la confección y elaboración de la revista", hallando un nuevo lenguaje formal que abandonara el "triunfalismo dogmático". En un mismo gesto se desmerecían los hallazgos del número anterior y se generaba una imagen simplista de la tan invocada y alabada cultura popular ${ }^{32}$. Estas cortapisas ayudan a explicar la aparición solo un año después de LFL como un espacio que, sin dejar de estar ligado a la UPA y a su marco ideológico, habilitaba un territorio de experimentación menos supeditado a este tipo de dictados orgánicos.

Viento del pueblo, 4, octubre de 1973, p. 4.

Ibid., p. 4.

"Editorial dirigido a los Compañeros Antifascistas", Viento del pueblo, 5, septiembre de 1974, s. p. 


\section{LFL: contracultura entre el esplendor y el ocaso de la izquierda radical}

Según Félix de la Torre Fajardo, integrante de LFL, el fracaso de las exposiciones organizadas por la UPA en los ateneos culturales de barrio provino de su reducción a lo que trataban de cuestionar: los conflictos entre artistas, los intentos de cooptación por los participantes próximos al PCE y la incomprensión popular: "todo acabó en intentar explicar cuadro por cuadro la exposición entera" ${ }^{33}$. Ello impulsó a que algunos de los miembros de la Comisión de Artistas Plásticos se plantearan en 1974 otras alternativas de intervención. Ahí se sitúa el germen de LFL. Sus integrantes coincidieron en el deseo de alumbrar un grupo vinculado a la UPA, pero que a su vez preservara su autonomía a la hora de imaginar nuevos modos de hacer para la inserción popular del arte:

había que dejar claro que una cosa era la militancia y otra el aspecto profesional (...) Así las cosas nos dividimos: los que trabajarían exclusivamente en el grupo y los que trabajaríamos en UPA y en la Familia con menor intensidad. Todas estas reuniones donde se dio forma al proyecto del grupo las hicimos en una casa vieja recién desocupada por sus propietarios. Era una casa enorme situada en el centro de Madrid, por todo mobiliario teníamos una cama de matrimonio y algunas sillas rotas. Los preparativos nos llevaron hasta bien entrado octubre ${ }^{34}$.

El núcleo fundador del grupo estuvo compuesto por Santiago Aguado, Darío Corbeira, Javier Florén, Amelia Moreno y Félix de la Torre Fajardo, a los que se unirían a partir de la primera exposición, Arte-contradicción (1975), Paco Gámez, Paco Leal y Juan López. La extracción social de sus integrantes era la clase obrera emigrada a Madrid durante el período desarrollista, un aspecto que era extensible a numerosos militantes de la UPA y el FRAP. A excepción de Corbeira, con estudios universitarios, el resto de los miembros se había autoformado en sus oficios y provenía de barrios humildes de la ciudad ${ }^{35}$. Uno de los aspectos más enfatizados era el carácter no profesional que asumía su actividad. Durante la visita que realizaron a Murcia en mayo de 1976, con motivo de la itinerancia de la exposición dedicada al Frente Polisario, Amelia Moreno aclaraba que cada uno de los integrantes de LFL tenía "su trabajo particular", con el cual aseguraban su existencia material, de modo que los ingresos derivados de la actividad artística se destinaban exclusivamente a autofinanciar los proyectos del grupo ${ }^{36}$. Desde su punto de vista, esa era la única garantía posible para poner en práctica una concepción crítica del arte que se alejara de las funciones asignadas por las clases dominantes y que, a su vez, trascendiera el horizonte subjetivo de la expresión individual. Esa desprofesionalización del arte en el ámbito de la producción tenía su correlato en el de la recepción. Se trataba de generar un arte para las mayorías que contribuyera a la constitución de un nuevo sujeto político -el pueblo- destinado a hacer estallar las contradicciones que atravesaban la vida social en el contexto del franquismo anterior y posterior a la muerte del dictador.

F. de la Torre Fajardo, "LFL. Una experiencia de arte popular", op. cit., p. 8.

Ibid., p. 9.

35 A diferencia de otros componentes, Corbeira poseía además un conocimiento directo de revistas especializadas en el arte neovanguardista internacional como Artforum. Por ese motivo, serían él y Félix de la Torre los encargados de escribir los textos producidos por el colectivo.

36 Cf. A. Andreu, “'El Cubri` y 'La Familia Lavapiés`. Una nueva forma de ver y hacer el arte”, La Verdad, Murcia, 18 de mayo de 1976 , p. 7. 
En el amplio abanico de las prácticas desmaterializadas de la época, LFL emerge como una muestra de "conceptualismo proletarizado" en la que resuenan las ideasfuerza que atravesaron proyectos pioneros del activismo artístico como Tucumán Arde: en ellos, la producción de subjetividad y de contrahegemonía implicaba el desplazamiento físico del cuerpo del artista a espacios ajenos al mundo del arte, así como la readecuación de sus formas de expresión y de sus medios de comunicación a un nuevo público ${ }^{37}$. La inclinación extra-profesional de LFL parece contrastar con la política emprendida desde finales de los sesenta por los sectores de artistas próximos al PCE, para los cuales la articulación entre la profesionalización del arte y la política cultural se había convertido en un vector de acumulación de fuerzas en el sector ${ }^{38}$. En todo caso, más que con una distinción de clase, ese contraste debería asociarse con una consigna que obtuvo amplio predicamento en los medios de la izquierda radical durante los años setenta, en especial en los entornos del maoísmo: las experiencias de "proletarización" o metodologías de aproximación como la "encuesta obrera" incentivaban una relación directa del militante con la realidad social de las clases subalternas ${ }^{39}$. La función social del arte se desplazaba más allá de la discusión entre la vigencia de los géneros tradicionales y la apertura a los nuevos lenguajes y medios de comunicación. El suelo subjetivo del artista era removido al exigirle suspender, de manera temporal o permanente, los rasgos de su identidad como agente cultural en la división social del trabajo.

Las dos exposiciones más relevantes de LFL, Arte-contradicción (1975) y Apoyo a la lucha del pueblo saharaui (1976), exploraron en un margen extremadamente estrecho de tiempo (coincidente con el final del franquismo con Franco y el cénit de la movilización social del franquismo sin Franco) una gama amplia de problemáticas, que iban desde las relaciones entre el arte, las instituciones y la sociedad hasta el compromiso con los procesos africanos de descolonización. En Arte-contradicción, inaugurada en abril de 1975, el uso de las estrategias características de la crítica institucional, interpretadas con mordacidad y una estética ecléctica, no se reducía a la visibilización de las relaciones de poder/ propiedad que operan en la trastienda de la institución arte, sino que reclamaba ese territorio como un espacio propicio para la lucha de $\operatorname{clases}^{40}$. Por su parte, la instalación en defensa del Frente Polisario, heredera de una visualidad más próxima a la crónica de la realidad practicada por el arte pop nacional y el mundo del cómic ${ }^{41}$, incomodaba las pretensiones del régimen

37 Cf. J. Vindel, Transparente opacidad. Arte conceptual en los limites del lenguaje y la politica. Madrid, Brumaria, 2015, pp. 72-98.

38 Cf. J. Albarrán, "Lo profesional es político: trabajo artístico, movimientos sociales y militancia política en el último franquismo", Espacio, tiempo, forma. Serie VII. Historia del Arte (N. Época), 3, 2015, pp. $245-271$. Pese a lo que argumento a continuación, en los espacios que se habilitaron durante esa época participaron también integrantes de LFL como Darío Corbeira, según se puede constatar en una de las actas (sin fecha) de las reuniones de la comisión Función del Arte en la Sociedad conservadas en el Archivo Redor-Calabuig del Centro de Documentación del Museo Nacional Centro de Arte Reina Sofía (Sección Asociación de Artistas Plásticos). La comisión formaba parte de los Grupos de Trabajo de Madrid, los cuales persiguieron, entre otros objetivos, "impulsar la creación de una asociación de artistas plásticos, modificar el plan de estudios vigente en la Escuela [de Bellas Artes] y disponer de una infraestructura que canalizase todo tipo de acciones contra la dictadura". Ibid., p. 250.

39 No parece casual que una de las piezas de autoría propia que elaboró por esos años Darío Corbeira se denominara justamente Una encuesta sobre la realidad (1976).

40 La exposición viajaría más tarde a la Escuela de Arquitectura de la Universidad Complutense de Madrid, a dos colegios mayores y a una sala de arte en Cuenca, tras lo cual los integrantes de LFL decidieron destruir las obras para no dejar resto que pudiera ser sometido a la lógica mercantil.

41 Un crítico de la época las asociaba a la obra de Lichtenstein. Cf. A. Moreno Mendoza, "La Familia Lavapiés", 
-así como las de una parte de la oposición- de provocar una integración democrática en las estructuras políticas, económicas y militares de Occidente, proceso que implicaba respetar los intereses de Estados Unidos en la región sahariana, coaligados con la política expansionista del reino marroquí. Difundidas mediante pintadas y carteles en los entornos universitarios y celebradas con inauguraciones masivas en la librería-galería Antonio Machado de Madrid, un espacio próximo al Partido Socialista Obrero Español (PSOE), ambas muestras se resistían por anticipado a los límites que la normalización democrática impondría sobre la articulación práctica entre militancia política y agencia cultural. Esa intervención en las condiciones del presente se basaba en un diagnóstico sobre las consecuencias de un cierre en falso de la coyuntura histórica que, si bien daría lugar a decisiones aventuradas como la intensificación de la lucha armada del FRAP, se vería corroborado por la deriva posterior de las políticas culturales y las culturas políticas de la Transición, con demasiada frecuencia enfangadas en el desencanto melancólico, la autonomía de la política y el tráfico de transacciones.

Forzada por las circunstancias materiales, la estética precaria y rococó del mobiliario kitsch de Arte-contradicción -fabricado por Javier Florén- se resistía a la sofisticación, sobriedad y asepsia que la crítica artística de raíz conceptual comenzaba a experimentar en su proceso de legitimación institucional. La elusión de la seriedad documental permitía a LFL deslizar una serie de contenidos políticos que ampliaban el horizonte de incidencia del arte politizado. En el catálogo editado para la muestra se explicitaban los siguientes objetivos, afines a las directrices ideológicas que hemos delineado:

a) Transcribir el país real en todos sus aspectos, dando una imagen lo más objetiva posible, a través de los distintos medios de comunicación.

b) Revisar, críticamente, el lenguaje artístico y adecuarlo, si fuera menester, a la situación actual en función de los grupos a los que va dirigido.

c) Articular una nueva crítica que inicie el análisis de nuestro pasado cultural y nuestra realidad cotidiana, para que contribuya, activamente, a orientar nuestro presente, abriendo perspectivas para un próximo futuro.

d) Sacar el arte de los recintos sacralizados por la tradición, donde el pueblo está ausente.

e) Enfocar colectivamente nuestros intereses culturales, artísticos y económicos ${ }^{42}$.

Una de las imágenes que aparecían en la exposición mostraba a la galerista Juana Mordó acompañada de los integrantes del grupo El Paso Rafael Canogar, Pablo Serrano y Juana Francés, de los pintores Lucio Muñoz y Matías Quetglás y de un "perrito" (Fig. 2). Mordó mostraba a los artistas un cuadro abstracto, presencia elocuente del éxito cosechado por el informalismo español. La confluencia entre las prácticas artísticas de vanguardia, la cosmética cultural del régimen franquista como forma diplomática de inserción estética en la comunidad internacional y la creación de un mercado del arte que dictaminaba la orientación de la creación plástica (una tendencia que no sería revertida por el tránsito a la democracia), era subrayada con sarcasmo mediante la cita de Quevedo que acompañaba a la escena: "no inspiracio-

Reseña de Literatura, arte y espectáculos, 96, junio de 1976, p. 40.

42 Arte-contradicción, 1975, p. 12. 


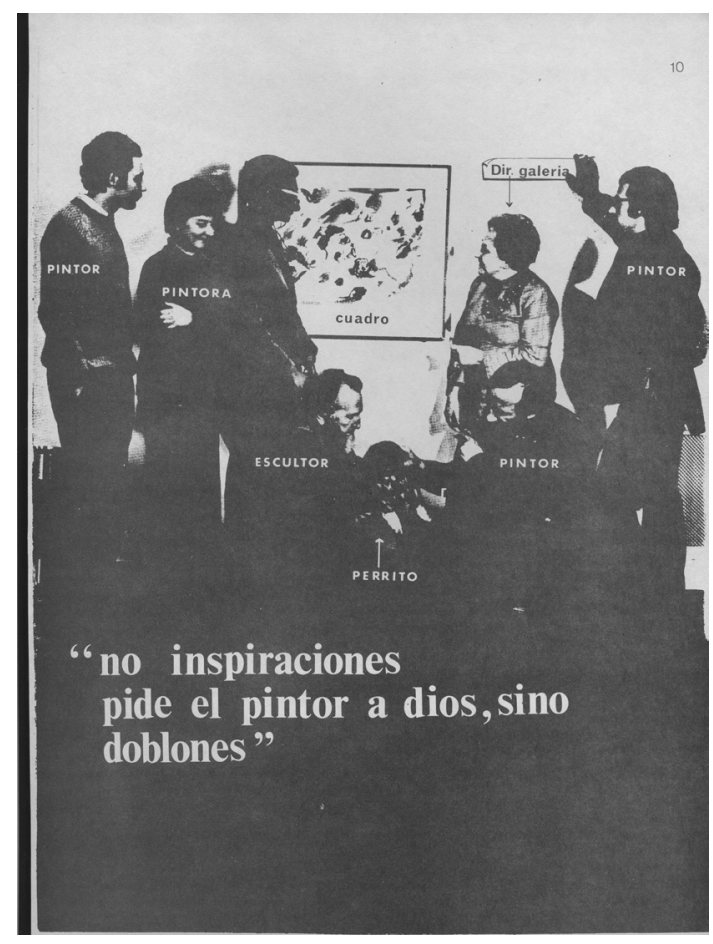

Figura 2. Página del catálogo de la exposición de La Familia Lavapiés Arte-contradicción, abril de 1975.

nes pide el pintor a dios, sino doblones" ${ }^{\prime 3}$. Esta crítica otorgaba continuidad a los señalamientos que Darío Corbeira había realizado en su artículo sobre los concursos de arte, publicado en el número 4 de Viento del pueblo. En él se diagramaba un gráfico sarcástico del sistema del arte en España, que establecía los vínculos orgánicos entre la Dirección General de Bellas Artes (Florentino Pérez Embid), el Comisario General de Exposiciones (Luis González Robles), el Opus Dei, las grandes empresas, los bancos y cajas de ahorro y los organismos públicos y ayuntamientos. Todas estas entidades eran las responsables de nombrar los jurados de los concursos de arte, tendentes a premiar a "sempiternos bodegonistas", "fabulosos paisajistas", "fascinantes retratistas" y "geniales innovadores rizadores del rizo", todos ellos "chicos muy majos (en el sentido fascista de la palabra)" que garantizaban dejar al margen la realidad social y cultural del país. En el texto que acompañaba el diagrama, se denunciaba "el interés del régimen fascista por impedir la creación y desarrollo de una cultura popular y su total y absoluta capacidad para potenciar una pintura de carácter y efectos reaccionarios" $" 4$.

Frente a un modelo de institucionalidad que despolitizaba la crítica, LFL aspiraba a construir una imagen dialéctica de las relaciones ente el arte y la sociedad. Para sus

$43 \quad$ Ibid., p. 10.

44 "Los concursos de arte", Viento del pueblo, 4, octubre de 1973, p. 10. Esos “efectos reaccionarios" se concretaban en la creciente mercantilización del arte, el alejamiento entre el arte moderno y la cultura popular y la falta de canales de promoción y difusión de los artistas no alineados con las estructuras culturales del régimen. 
integrantes no se trataba tan solo de cuestionar la vigencia de los géneros artísticos tradicionales o el papel que cumplía la mediación institucional en la comprensión social del arte, sino que era además necesario articular las metodologías emergentes de producción artística con la búsqueda un nuevo público para el arte. El deseo de alterar la inercia artística del país como modo de abrir los futuros posibles se sedimentaba en una concepción de los dispositivos y los discursos que se hacía cargo de las tensiones económicas y políticas del presente, con el objetivo de impugnar aquellas formulaciones de la cultura que pretendían situarse por encima de las contradicciones de clase. En el catálogo de la muestra, estas aparecían figuradas por sujetos sociales que se situaban más allá de los problemas específicos que aquejaban al mundo del arte. Los agentes de ese sistema (el mecenas, el artista) formaban parte de una cadena alegórica de imágenes que desbordaba sus límites simbólicos, incorporando una fotografía de los fusilados en el cuartel de la Montaña, una caja fuerte de un banco, la nómina de un obrero $\mathrm{y}$, finalmente, los entornos cotidianos del transporte metropolitano (el autobús y el metro), que -al tiempo que rescataban del olvido cultural ámbitos rutinarios de la vida urbana- extendían de modo metafórico el espectro político emergente de las fuerzas sociales que habían permanecido soterradas durante la larga noche del fascismo ${ }^{45}$.

Un año más tarde, la exposición ideada en colaboración con el Frente Polisario incorporaría de manera más audaz medios de expresión y comunicación extrapictóricos (con especial énfasis en el montaje fotográfico y el collage fototextual) para denunciar la represión sufrida por el pueblo saharaui ${ }^{46}$. La "operatividad práctica" de los nuevos formatos y espacios de exhibición implicaba una apuesta por la desprofesionalización del arte que se remontaba a las versiones productivistas de las vanguardias históricas, cuyo influjo en otras geografías coetáneas durante los años sesenta y setenta ha sido objeto de revisión historiográfica ${ }^{47}$. El amateurismo derivado de la desmitificación del artista burgués fue en este sentido un paso previo para la inscripción de la praxis del arte en los conflictos sociales. La propia constitución colectiva de LFL parecía disolver el aura que la expresividad informalista había vertido sobre los discursos artísticos. El genio autorial, deudor de una tradición despolitizada del quehacer plástico, se había ceñido en el arte español posterior a la Guerra Civil a una genealogía que actualizaba las esencias espirituales e hispánicas de una cultura barroca, eterna e imperial ${ }^{48}$. Su sátira burlesca en el contexto del tardofranquismo se relacionaba con una disputa por el concepto de vanguardia, cuyo precedente más

$45 \quad$ Así lo manifestaba Darío Corbeira en una de las entrevistas que nos concedió para la realización de este trabajo. El gesto resultó premonitorio, si consideramos que la huelga de los trabajadores del metro de Madrid a principios de 1976 fue una de las más salvajes entre las que se sucedieron durante los meses inmediatamente posteriores a la muerte del dictador.

46 Un crítico de la época lo sintetizó de este modo: "Dentro del entorno, que contextualiza el propio alcance iconográfico de la exposición, destaca, como objetivo primordial, la tremenda carga ideológica en su dimensión comunicativa, una dimensión que aquí se cumple de manera fácil y sugerente. Por una parte, la imagen de una realidad vital, la del pueblo en lucha por su libertad -de concepción sintáctica plenamente fotográfica-; por otra, la imagen del trasfondo generador del problema (colonialismo-imperialista) (...) En suma, lo que LFL nos muestra en esta segunda exposición no es más que el intento (...) de poner al descubierto un problema que nos incumbe a todos, dando al arte motivo para huir de su objeto tradicional, confiriéndole el valor expresivo de su operatividad práctica". A. Moreno Mendoza, op. cit., p. 40.

47 En relación con los desarrollos factográficos de la vanguardia argentina, puede consultarse J. Vindel, “An operative conceptualism: factography and counter-information in the argentinian cultural avant-garde of the 1960s", en: G. Schöllhammer y R. Arevshatyan (eds.), Sweet Sixties: specters and spirits of a parallel avantgarde. Berlín, Sternberg Press, 2013, pp. 158-169.

48 Cf. J. L. Marzo y P. Mayayo, Arte en España (1939-2015): ideas, prácticas, políticas. Madrid, Cátedra, 2015. 
conocido tal vez sea la polémica sostenida durante 1973 por Antoni Tàpies y los miembros de otro colectivo artístico de la época, el Grup de Treball ${ }^{49}$.

Para la LFL, el pragmatismo político del arte no podía sustraerse a la necesidad de que sus artefactos transitaran, en clave marxiana, desde el valor de cambio al valor de uso. Para ello, la impugnación de la figura consagrada del genio artístico debía articularse con la búsqueda de nuevos agentes que se involucraran activamente en la visualización de los conflictos políticos. Con acento antiimperialista y anticolonial, la exposición en apoyo del pueblo saharaui involucró en un debate común a los miembros de LFL y la Sociedad de Amigos del Sahara, afín al Frente Polisario. En el documento-catálogo informativo que acompañó a la exposición se radiografiaban las causas económicas del conflicto desde una perspectiva geopolítica que subrayaba la lucha por los recursos materiales del territorio saharaui. En sus páginas se incluían collages fotoperiodísticos de denuncia (como los relativos al interés de los Estados Unidos en los fosfatos de la zona), proclamas por las luchas de liberación nacional de los países norteafricanos ${ }^{50}$ y esquemas ideológicos del conflicto que incitaban a que el espectador se convirtiera en "protagonista" de la historia.

La estética precaria de esas páginas era compartida también por el montaje de imágenes realizado con motivo de la muestra en la librería-galería Antonio Machado $^{51}$. Allí, dos bloques de siluetas eran confrontados en el espacio de la sala. En el lado externo de la superficie cóncava central, las fotocopias ampliadas con los combatientes polisarios y el pueblo saharaui en armas. Frente a ellos, las figuras de cartón de la Marcha Verde, con las fuerzas imperialistas de ocupación estereotipadas: el soldado, el dirigente político, el hombre de negocios, el marine. La escenificación se completaba con arena del desierto esparcida por el suelo (que replicaba en un formato politizado la Earth Room de Münich ideada en 1968 por Walter de Maria), una zona reservada a la recogida de alimentos y dinero, un muro destinado a la participación del público donde se recogían consignas de apoyo y un espacio con revistas y periódicos con información relativa al conflicto (Fig. 3). Se trataba de crear un ambiente de apariencia mimética que aproximara al espectador a la tonalidad afectiva de la vida militante. Si bien antecedía las propuestas de artistas contemporáneos como Thomas Hirshorn, este prototipo de "exposición militante" 52 debe ser contemplado como síntoma de las condiciones de producción del proyecto. $\mathrm{Su}$ aparente precariedad material y estética era el reverso de su inscripción política en un contexto marcado por la premura activista y en el que la exaltación de las luchas anticolonialistas debía inspirar, en su traducción maoísta, la actualización de la Guerra Civil en territorio español.

49 Los intercambios de la polémica aparecen recopilados en Grup de Treball. Barcelona, MACBA, 1999, pp. 5161.

50 En relación con este aspecto, el punto número 5 del documento redactado por el Comité Coordinador pro-FRAP ya apostaba por la "liquidación de los restos del colonialismo español". La exposición de LFL se produjo con posterioridad al abandono del territorio saharaui por parte de la administración y el ejército españoles, que facilitaron la Marcha Verde y la ocupación por parte de Marruecos y Mauritania. Los contactos entre el FRAP y el Frente Polisario se intensificaron en 1975. En junio de ese año, las delegaciones del Comité Permanente del FRAP y de la dirección del Frente Polisario se entrevistaron en Argelia, emitiendo un comunicado conjunto que se publicaría en el n ${ }^{\circ} 26$ de Acción, órgano de expresión del FRAP, cf. Equipo Adelvec, FRAP. 27 de septiembre de 1975, op. cit., p. 101.

51 La exposición viajaría más tarde a la Universidad Complutense de Madrid y a Murcia.

52 Así la calificó Darío Corbeira durante una las conversaciones mantenidas con el autor. 


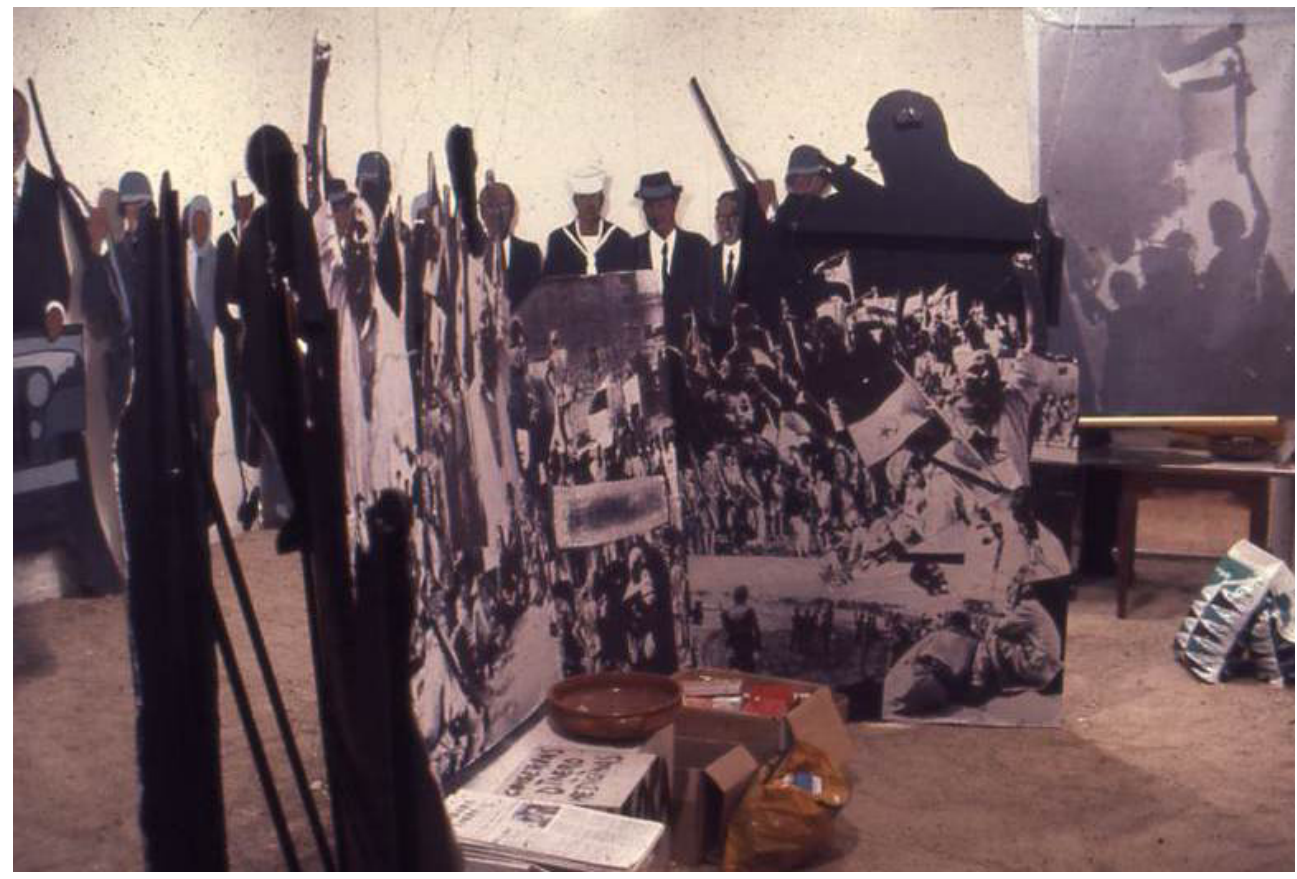

Figura 3. Exposición de La Familia Lavapiés en Apoyo a la lucha del pueblo saharahui, febrero de 1976.

\section{La disputa por la memoria y el territorio}

Frente al apaciguamiento de la memoria que preconizaba la doctrina de la reconciliación nacional amparada por el PCE, las acciones de LFL retomaban diversos elementos simbólicos relacionados con la Guerra Civil para reconstituir una concepción conflictiva de su memoria que se inscribiera en el presente político. En este campo de tensiones, la evocación de Miguel Hernández resultó recurrente. La ficción periodística conocida como El Caso, fechada en Madrid el 15 de mayo de 1976 y editada por Paco Gámez ${ }^{53}$, se constituía en un montaje fototextual que, a modo de "retrato del crimen" del poeta, adoptaba la apariencia de una publicación popular homónima dedicada a la crónica de sucesos, con gran difusión durante la dictadura militar (Fig. 4). En la portada, una fotografía de Hernández era asociada a una descripción de sus rasgos faciales. La leyenda que la acompañaba sugería que esa fotografía podría haber facilitado su detención por la policía, quien lo acusara "de ser comisario comunista, de intervenir en conferencias y mítines, escribir versos injuriosos para las fuerzas nacionales, realizar una intensa propaganda contra los integrantes de la quinta columna, contribuyendo con hechos y palabras a los muchos crímenes perpetrados

53 Gámez, integrante de la Comisión de Pintura de la UPA y posterior miembro de LFL, fue encarcelado como parte de las represalias por los acontecimientos del 1 de mayo de 1973, cuando un integrante del FRAP hirió de muerte a un miembro de la Brigada Político Social durante las reyertas callejeras que se sucedieron ese día. Tras ingresar en la prisión de Carabanchel, le echaron de su trabajo en Correos y hubo de abandonar la carrera de Sociología. Gámez diseñó algunos números de Viento del Pueblo, así como carteles con la imagen de Miguel Hernández para los actos que organizaban en las asociaciones de barrio. En la entrevista que nos concedió, recalcó que en ningún momento LFL tuvo la intención de integrarse en el mundo del arte. 


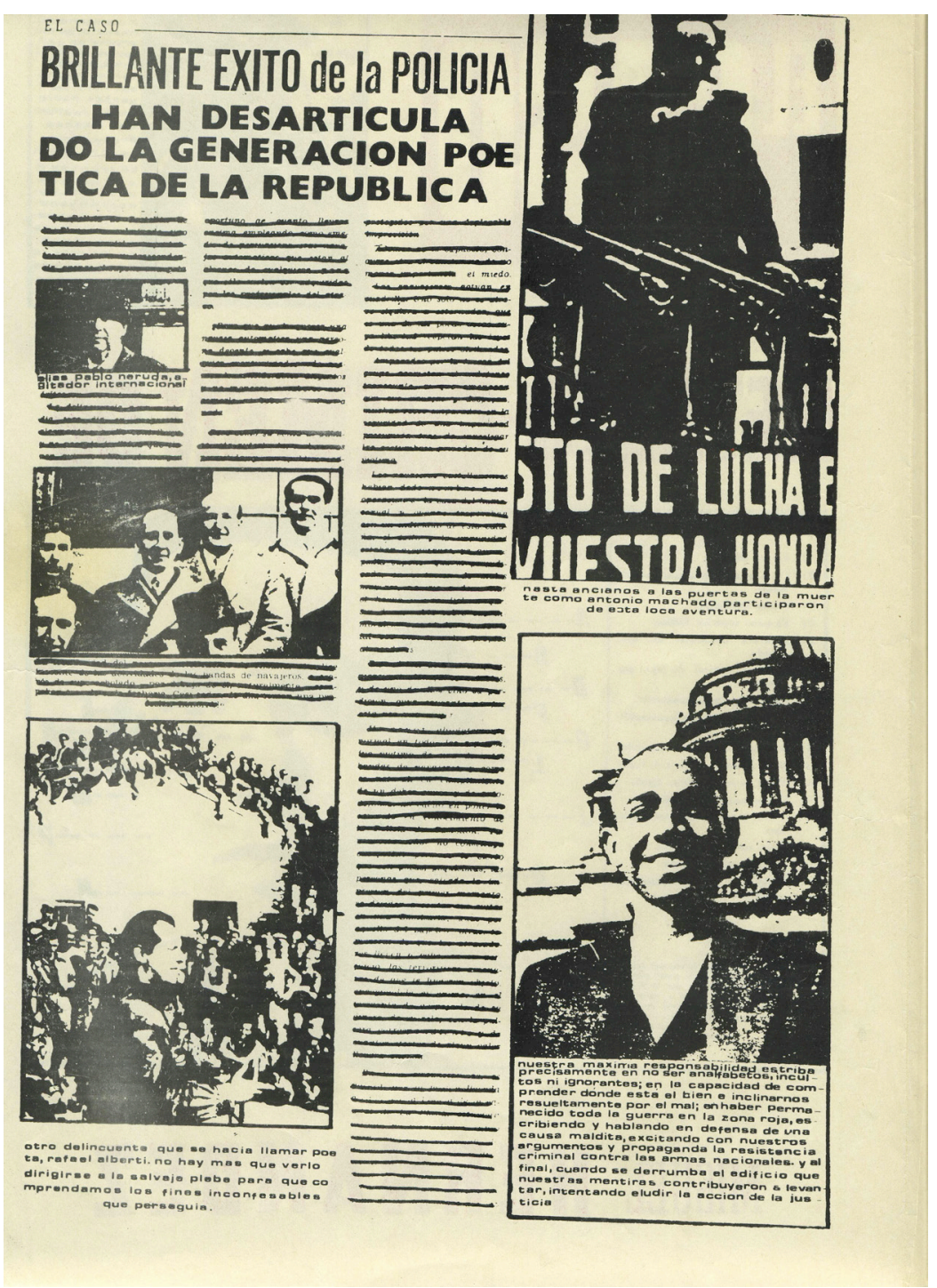

Figura 4. Unión Popular de Artistas y La Familia Lavapiés, publicación El Caso, mayo de 1976.

en la zona roja". La primera página interior correspondía a una noticia encabezada por el titular "Brillante éxito de la policía. Han desarticulado la generación poética de la República", cuyo texto se encontraba borrado por una línea continua, en una alusión directa a las condiciones de censura que afectaban a la cultura crítica bajo la dictadura. Únicamente se podía leer el pie de foto junto a una imagen de Rafael Alberti en la que se le tachaba de "delincuente". A continuación, la siguiente página incluía un reportaje ilustrado en homenaje a Miguel Hernández, resignificado por un relato escrito sobre las venturas y desventuras de "El Lute". La "obsesión por la libertad" que identificaba al prófugo de la justicia parecía conceder un hálito de vida a la suerte corrida por el poeta alicantino en las cárceles del franquismo. En la 
contraportada, se glosaba el entierro de Hernández en el cementerio de Alicante. Un testimonio anónimo señalaba que sus seres queridos no habían podido velar su cadáver debido a que "los empleados del cementerio nos dijeron que por la noche llevaban gente a fusilar", un elemento que convocaba el recuerdo inmediato de la muerte de los tres militantes del FRAP asesinados por el franquismo en septiembre de 1975. Esos militantes habían encarnado la invocación redentora de la juventud española realizada por Hernández en el poema "Recoged esta voz", incluido en el libro Vientos del pueblo, publicado en 1937 y uno de cuyos fragmentos se incluía en la misma página: "la juventud de España saldrá de las trincheras de pie, invencible como la semilla". El montaje de la LFL concluía finalmente con un extracto de la dedicatoria a Vicente Aleixandre que abría ese mismo poemario, donde Hernández apostaba por conceder un contenido social más explícito a sus versos: "Nuestro cimiento será siempre el mismo: la tierra. Nuestro destino es parar en las manos del pueblo. Sólo esas honradas manos pueden contener lo que la sangre honrada del poeta derrama vibrante. Aquel que se atreve a manchar esas manos, aquellos que se atreven a deshonrar esa sangre, son los traidores asesinos del pueblo y la poesía, y nadie los lavará: en su propia suciedad quedarán cegados" ${ }^{54}$.

Este microdispositivo editorial, tan precario como mordaz, fue producido por la Comisión de Pintura de la UPA con motivo de la celebración en la Facultad de Filosofía II de la Universidad Complutense de Madrid (UCM) del homenaje a Miguel Hernández en el 35 aniversario de su muerte ${ }^{55}$. Su distribución entre los asistentes adoptó la forma de un happening que reproducía la difusión habitual del periódico en la vía pública. Para la misma efeméride, la Promotora Artes Plásticas S. A. (APSA, registrada el 30 de junio de 1972) se propuso redactar un manifiesto que refleja la influencia de la izquierda radical en los debates que se produjeron al interior de los círculos de artistas politizados. Próximo a las posiciones defendidas por organizaciones como la UPA, la Organización Revolucionaria de Trabajadores (ORT, también maoísta) o la Liga Comunista Revolucionaria (LCR, de tendencia trotskista), el "Proyecto para Manifiesto de artistas", fechado en febrero-marzo de 1976 y conservado en el Archivo Marchán/ Quevedo del Centro de Documentación del Museo Nacional Centro de Arte Reina Sofía, retomaba literalmente y ampliaba los puntos programáticos contenidos en el catálogo de la muestra Arte-contradicción, que LFL había organizado unos meses antes. Al inicio del documento se clarificaba que "un grupo de Profesionales del Arte y de la Cultura, hemos mantenido a lo largo de estos meses -coincidiendo con la preparación (...) del Homenaje de los Pueblos de España a Miguel Hernández y conscientes de su significado, - una serie de reuniones". A continuación, el borrador explicitaba una reivindicación política de la memoria de la II República que entraba en conflicto con la táctica del PCE, cada vez más partidario de renunciar a la ruptura con el Estado franquista y aceptar una reforma pactada con los elementos no continuistas del régimen. La exhibición de la bandera tricolor durante el acto en la UCM enconaría de hecho los ánimos entre los militantes de la izquierda radical y los simpatizantes del $\mathrm{PCE}^{56}$. La fecha de redacción del manifiesto

El Caso. Retrato-crimen de Miguel Hernández. Madrid, 15 de mayo de 1976. pp. 1-4.

55 Una breve crónica de estas jornadas, que durante tres días incluyeron coloquios, conferencias y la participación de poetas, músicos y artistas como Blas de Otero, Enrique Cerdán Tato, Aguaviva, Enrique Morente, Adolfo Celdrán, Juan Genovés o Arcadio Blasco, puede leerse en A. Sorel, "Homenaje a Miguel Hernández en la Complutense", Posible, no 74, 10 de junio de 1976, p. 44.

56 Algunos de los reclamos que distanciarían las ambiciones rupturistas de la izquierda radical de la inercia 
coincidía con el cenit del ciclo de huelgas y protestas impulsadas por el movimiento obrero y diversos sectores sociales. Las movilizaciones se habían visto intensificadas tras la muerte de Franco y durante el gobierno de Arias Navarro, deparando confrontaciones cuasi insurreccionales entre el movimiento obrero y la población organizada y los patrones de las fábricas y las fuerzas represivas del régimen. Tal vez el caso más significativo fueron los acontecimientos de Vitoria durante el primer trimestre de 1976, cuyo desenlace trágico el 3 de marzo fue la masacre de los trabajadores reunidos en asamblea en la iglesia de San Francisco de Asís ${ }^{57}$. En la declaración de los artistas se incluían presupuestos políticos que remiten directamente a los principios de la UPA, el FRAP y el PCE (m-l), como la reclamación fundada en "la tradición federalista" y republicana del derecho de autodeterminación de los pueblos o reflexiones en torno a la función social del arte que determinaban:

la obligación de los artistas a incorporarnos en diversas formas de lucha por [la] transformación radical de las estructuras, pues solo en el marco de la nueva sociedad se darán: por un lado, las condiciones para que el arte se convierta en patrimonio social y, por otro, las bases que acaben con la dicotomía actual entre arte de vanguardia y arte de masas. ${ }^{58}$

El noveno punto del manifiesto recogía los "planteamientos" o propuestas de los artistas para llevar a efecto ese proyecto. Es significativo que los tres primeros coincidieran en su totalidad con los que figuraban en el manifiesto incluido en el catálogo de Arte-contradicción. Los objetivos restantes se sintetizaban del siguiente modo:

d) la necesidad de una enseñanza científica y al servicio del pueblo de la teoría y la práctica artísticas; e) el deber de buscar las raíces de la cultura popular para convertirlas en punto de partida de nuestros objetivos; f) la necesidad de una organización de profesionales del sector que enfoque y canalice colectivamente nuestros intereses y aspiraciones culturales, artísticas y económicas; g) la creación de nuevos cauces y medios para la distribución de nuestra obra, lo que entendemos que sería viable dentro de un régimen cooperativista; h) la adhesión a todos los sectores y asociaciones -de vecinos, de profesionales, etc.- que planteen montajes

reformista del PCE serían la constitución de un gobierno provisional que condujera el proceso transicional hasta las primeras elecciones legislativas, la realización de un referéndum sobre la forma de Estado (monarquía o república) como parte de un proceso constituyente, el reconocimiento del derecho de autodeterminación de los pueblos o la desarticulación y enjuiciamiento de las estructuras represivas del estado franquista (policía, Guardia Civil y ejército). Cf. G. Wilhemi, Romper el consenso. La izquierda radical en la Transición española (1975-1982). Madrid, Siglo XXI, 2016.

57 Ante esa situación, Juan Carlos de Borbón, jefe de Estado designado por el franquismo, tomó poco más tarde la decisión de sustituir el gobierno continuista de Arias Navarro por el reformista de Adolfo Suárez (julio de 1976). Por su parte, semanas después de los sucesos de Vitoria el PCE decidía converger con el PSOE en el espacio de Coordinación Democrática (la conocida como "Platajunta"), resultante de la fusión de la Junta Democrática (auspiciada por el PCE) y la Plataforma de Convergencia Democrática (controlada por el PSOE). La dirección del partido pretendía otorgarse una imagen de respetabilidad y moderación a costa de desmovilizar la actividad de sus bases en las luchas sociales en curso, que amenazaban con desbordar los cauces pactistas aceptados por la organización. La autonomía de lo político que caracterizaría el proceso transicional encontraba aquí su anclaje fundacional en lo relativo a la oposición democrática, que hegemonizada por esos dos partidos se distanciaría progresivamente de los reclamos rupturistas de la izquierda radical. Cf. E. Rodríguez López, Por qué fracasó la democracia en España. La Transición y el régimen del '78. Madrid, Traficantes de Sueños, 2015.

58 "Proyecto para Manifiesto de artistas", febrero-marzo de 1976, APSA. Archivo Marchán/ Quevedo del Centro de Documentación del Museo Nacional Centro de Arte Reina Sofía. Carpeta Nuevos comportamientos artísticos, España, caja II, Conceptualismos en el contexto de la Institución Arte, la Cultura y la Política, nº 13, s. p. 
culturales y artísticos lejos de las galerías sacrilizadas [sic] por la tradición y de los que el pueblo se ha hallado y se halla ausente. ${ }^{59}$

La convocatoria en la UCM se complementó con el homenaje que los Pueblos de España rindieron a Hernández en su localidad natal, Orihuela (Figs. 5 y 6). En esa ocasión los miembros de LFL realizaron una serie de caretas con el rostro del poeta que portaron durante el transcurso de la marcha que se organizó por las calles de la localidad. Además, se imprimieron estarcidos sobre los muros de diferentes

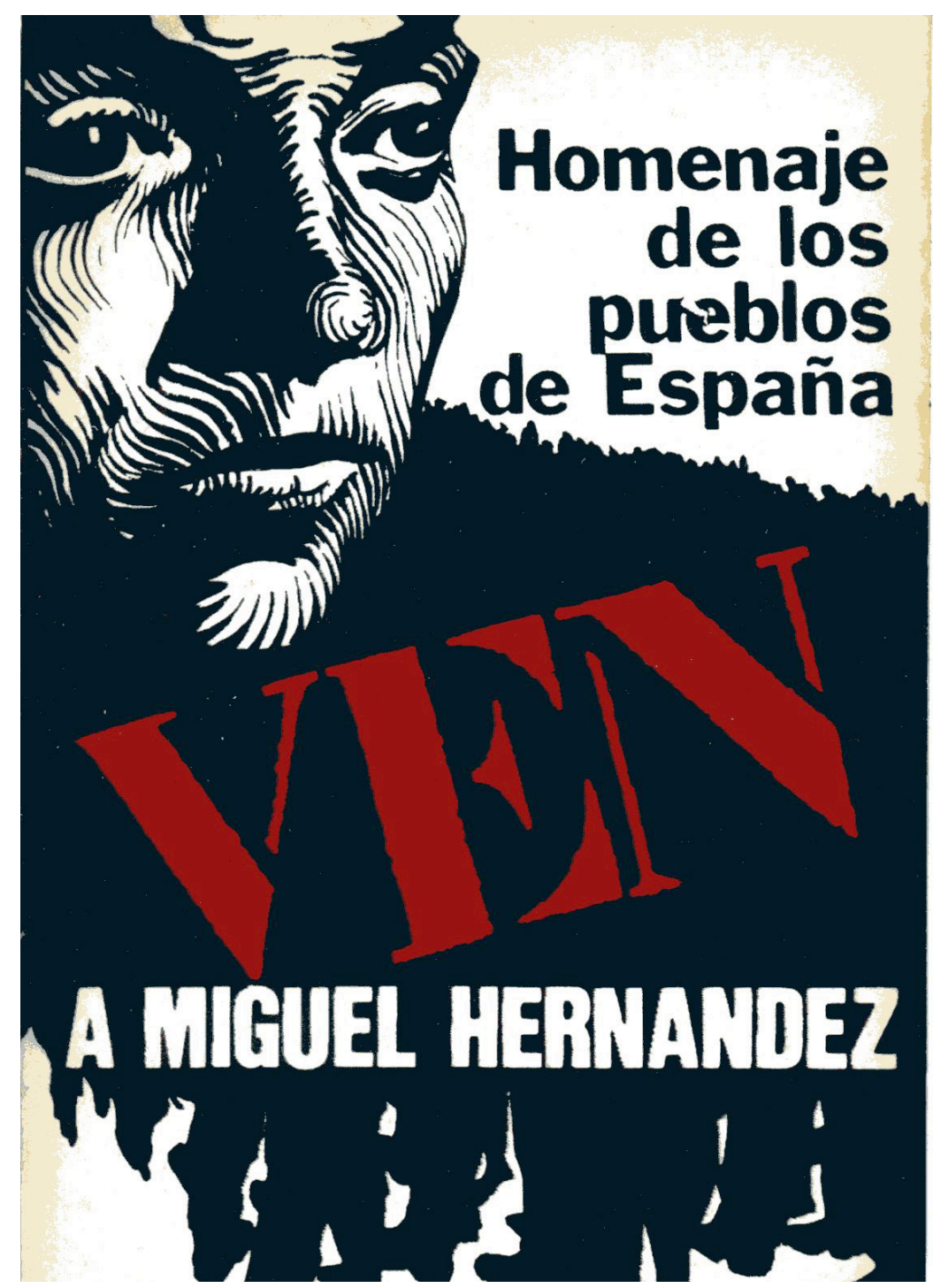

Figura 5. Convocatoria del "Homenaje de los Pueblos de España a Miguel Hernández". 


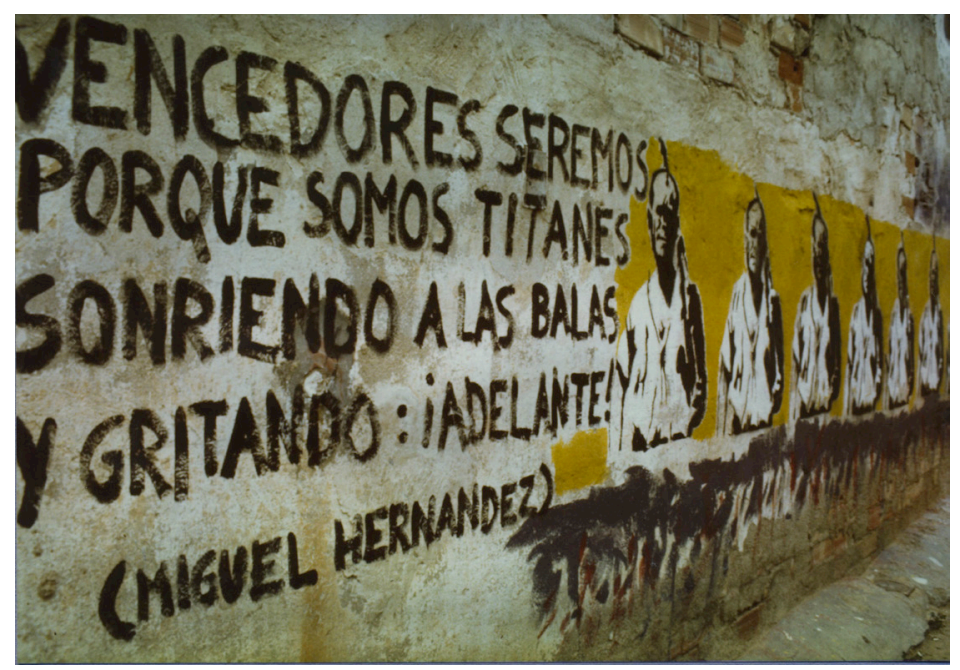

Figura 5. Intervención mural de La Familia Lavapiés, Orihuela, 17 al 27 de mayo de 1976.

edificios en los que se recuperaba la mítica figura del campesino miliciano con el fusil al hombro mediante una estética pop próxima al imaginario de colectivos como el Equipo Crónica ${ }^{60}$. Esa figura se inscribía a su vez en las coordenadas ideológicas del maoísmo, que en la versión de las tesis del PCE (m-1) seguía otorgando un papel central a la población de las zonas rurales como impulsora de una insurrección general. El levantamiento popular, cuya activación había guiado los atentados del FRAP durante el verano de 1975, debía conducir a las clases subalternas a sostener una guerra prolongada que acabara con la dictadura y gestara una república democráticonacional ${ }^{61}$. El "enfoque «tercermundista» de la historia", presente en la poética anticolonial de la izquierda cultural de la época, pasaba por alto la composición social de la España coetánea, tramando una genealogía de las luchas del siglo XX en la que la Guerra Civil española se constituía en una suerte de vértice (y de vórtice) geohistórico que, en un mismo gesto, resignificaba y era resignificada por los procesos de emancipación impulsados con posterioridad por otros "condenados de la tierra". España, en su doble condición de centro y periferia, de norte y sur, de metrópoli y colonia, escenificaba así el desgarro de todo un siglo.

La intervención en Orihuela muestra el énfasis que LFL siempre puso en la relación de sus acciones con el contexto social específico en que se desplegaban. Esto

60 Un registro de esa acción puede verse en el siguiente enlace: htps://www.youtube.com/watch?v=_IPV_KhZiU4. En la intervención en la universidad la imagen del campesino miliciano encontró su contrapunto de género en una mujer campesina que también portaba un fusil.

${ }_{61}$ No por casualidad, en el número 3 de Viento del pueblo se publicaba un artículo titulado "Apoyar la lucha por el campesinado es tarea de los artistas e intelectuales antifascistas", donde se incidía en que ese sector social seguía representando al $30 \%$ de la población (unos diez millones de personas). Aunque se constataba su éxodo hacia los barrios periféricos de las grandes ciudades, se subrayaba igualmente que "aún viven y trabajan en el campo millones de familias que se ven progresivamente amenazadas por la indiscriminación [sic] política de importaciones de excedentes agrícolas norteamericanos y de otros países" y se interpelaba a los artistas mediante un "urgente llamamiento a realizar obras sobre el campesinado y a desarrollar todo tipo de actividades artísticas (recitales, actuaciones, representaciones, proyecciones, conferencias...) en los pueblos campesinos del país" y a formar "grupos de artistas que recojan y expresen la situación de nuestros compañeros del campo". Viento del pueblo, 3, diciembre de 1972, p. 18. 
afectaba tanto a su participación en eventos organizados por el movimiento vecinal como a las exposiciones realizadas en los ateneos culturales. Estas últimas solían ir acompañadas de una presentación pública que funcionaba como disparador de charlas informales con los asistentes. En opinión de Darío Corbeira, la frustración artística e ideológica que con frecuencia entrañaban esos encuentros se veía compensada por la trama afectiva que construían. En esa trama no solo coincidían con los vecinos del barrio, sino también con militantes de otras organizaciones de la izquierda radical como la ORT o la LCR. En el plano político, la presencia territorial de LFL se correspondía con uno de los núcleos de actividad de la izquierda radical y, en particular, de las organizaciones a las que se vinculaba: la incidencia en el tejido popular de los barrios de Madrid ${ }^{62}$. El PCE (m-l) se había involucrado en las COB (Comisiones Obreras de Barrio), inscritas en los círculos de socialización del movimiento vecinal y que, además de aportar soluciones a los problemas cotidianos que afectaban a la vida social a esa escala territorial durante la etapa final del franquismo, perseguían una politización de ese impulso cívico con la intención de rehabilitar la función que los los comités revolucionarios populares habían tenido durante la guerra civil. En el plano artístico, esos entornos eran pensados como espacios de intervención en los que ensayar dispositivos comunicativos y de producción de subjetividad que conciliaran los reclamos orgánicos de arraigo cultural en el conflicto social con los lenguajes y modos de hacer de las prácticas neovanguardistas.

Esta tensión explica la simultaneidad de propuestas de signo contrario que atravesó la aportación que LFL realizó para la convocatoria que el movimiento vecinal del barrio madrileño de Portugalete difundió en junio de $1976^{63}$. Con motivo de las fiestas de San Pablo del año anterior, se reclamó la participación en la alteración visual del paisaje urbano de aquel segmento de la comunidad artística con el que el movimiento vecinal mantenía una mayor complicidad política ${ }^{64}$. Esa colaboración encontró continuidad en las celebraciones del año siguiente, para las cuales LFL diseñó un mural que se adaptaba a la modalidad artística prevaleciente en esa y la anterior convocatoria de las fiestas. La obra enlazaba con una tradición moderna en la articulación estética entre arte y política reconocida como válida al interior de la $\mathrm{UPA}^{65}$. Sin embargo, su iconografía fue resignificada mediante una performance que

${ }^{62}$ Alberto Berzosa ha reconstruido en una exposición reciente las sinergias entre la militancia política y el activismo artístico en el Madrid de los años setenta, cf. Inéditos 2016: Del barrio a la democracia. Madrid activismos (1968-1982). Madrid, La Casa Encendida, 2016.

63 La Asociación de Vecinos del Barrio de Portugalete había surgido en 1973 para oponerse al Plan de Ordenación de Ciudad Lineal (1972), que pretendía incrementar la concentración y altura edificativas, así como construir dos autopistas que atravesarían el barrio. Además de oponerse al plan, la Asociación denunció la carencia de infraestructuras básicas en las viviendas, que padecían problemas de hacinamiento, ventilación, humedades e inflación en los precios del alquiler. Junto a este problema, Isabel García García añade "la ausencia de guarderías, centros sanitarios, instalación de aguas, alcantarillado y pavimentación de calles, limpieza general del barrio, instalaciones deportivas y recreativas, transportes, servicios de prensa y correos, residencias para ancianos o mercado", cf. Isabel García García, "Barrios intervenidos artísticamente durante el último franquismo", Arte y Ciudad. Revista de Investigación, junio de 2013, 3 (I), extraordinario, pp. 613-614.

64 Una reconstrucción de este evento puede leerse en Ibid., pp. 611-640.

65 Así lo testimonian algunos de los documentos conservados en el ADC, como la loa a la figura de David Alfaro Siqueiros contenida en uno de ellos. El pintor mexicano habría representado un ejemplo del "artista militante" involucrado en las vicisitudes de la Revolución mexicana y de la Guerra Civil española, en la que participó como voluntario internacional. Reproduciendo el tópico indigenista de un sector de la izquierda mexicana, el documento consideraba que su muralismo había recuperado las tradiciones populares ancestrales de las civilizaciones prehispánicas, destruidas con anterioridad por el imperialismo español. Siqueiros se constituía así en un referente para la refundación de un "arte épico del presente" que manifestara la "esperanza firme en la victoria" y el mural en aquella modalidad plástica "definitiva" y "trascendental" para facilitar el alcance 
escenificaba las contradicciones de clase y las fuentes del poder material y espiritual que condicionaban la realidad social española del tardofranquismo.

El mural mostraba sobre un fondo rojo la presencia de dos grupos de figuras, símbolo de la diáspora popular ocasionada por la derrota del bando republicano en la Guerra Civil ${ }^{66}$. La imagen aparecía quebrada por tres líneas que remitían a los colores de la bandera republicana, la última de las cuales encerraba un fragmento del Guernica de Picasso. El mural componía así un campo de color (color field) sobre el que la connotación semántica de la abstracción lineal era reforzada por el collage figurativo, que enlazaba por partida doble la imagen con el conflicto civil de los años treinta y los éxodos bélicos instalados en el inconsciente óptico de la Guerra Fría, con el conflicto en Vietnam como trasfondo. Finalmente, en un lateral del muro, los integrantes de LFL incluyeron la consigna "La ciudad debe ser nuestra". El fragmento pictórico extraído del Guernica y la proclama adyacente interpelaban a otros dos murales producidos durante esos días. Por un lado, se trataba de ampliar el alcance territorial del mural "El barrio es nuestro", pintado durante el mismo evento por El Cubri, así como de otorgar un matiz imperativo al título de la convocatoria vecinal: "La ciudad es nuestra" 67 . Por otro, de revitalizar el legado político del Guernica más allá de su conversión en icono de la izquierda política. Los integrantes de LFL detectaban ese riesgo en la versión mural del cuadro de Picasso que el equipo de Agustín Ibarrola pintó ese año como telón de fondo tanto de los conciertos musicales como del Mercadillo autoconstruible diseñado por José Miguel de Prada Poole para albergar los puestos de venta de arte popular durante las fiestas ${ }^{68}$. Sin embargo, la pobreza del resultado plástico, así como la experiencia estética contemplativa que prevalecía entre los vecinos del barrio, indujo a la LFL a ir un paso más allá y completar su mural con una performance en las que sus miembros se disfrazaron para figurar la dialéctica entre la clase obrera y las fuerzas conservadoras que sostenían las estructuras del régimen: la Iglesia, el capital y el fascismo (Fig. 7) ${ }^{69}$. La acción fue interpretada por los convocantes y los vecinos del barrio como una provocación, lo que motivó que expulsaran a los integrantes de LFL del espacio festivo.

pedagógico del arte político, s.f., s.f. ADC.

${ }_{66}$ Los integrantes de LFL ya habían realizado con anterioridad un mural similar en el barrio de la Ventilla. En esa ocasión, idearon también una acción consistente en embalar la plaza pública del barrio. La intervención se inspiraba en la obra de Jeanne-Claude, que Darío Corbeira había conocido gracias al libro editado por Germano Celant Art povera. Conceptual, Actual or Impossible Art (Londres, Studio Vista, 1969), y se completaba con el despliegue de una pancarta donde se podía leer "se vende esta ciudad". A modo de denuncia de los planes urbanísticos que se beneficiaban de la venta de suelo público, la consigna anunciaba la apertura de una nueva era en la que neoliberalismo especulativo situaba su trinchera de avanzada en la actuación de los poderes del estado.

67 Ese fue el título del documental que Tino Calabuig grabó en 1975, donde el artista se aproximaba a los testimonios de miembros de las asociaciones de vecinos de barrios de Madrid como Orcasitas, el Pozo del Tío Raimundo, San Blas o el Barrio del Pilar.

68 Noemí de Haro ha subrayado que si bien estas "arquitecturas hinchables" remitían a modelos ya experimentados anteriormente por el arquitecto español (Prada Poole fue el autor de la cúpula neumática que albergó la sede principal de los Encuentros de Pamplona en 1972, que acabaría por constituirse en icono visual de ese evento), la denominación que adquirieron como "jaimas" en las fiestas de Portugalete debe vincularse a las tiendas saharauis, "un homenaje que seguramente no fue casual puesto que se producía tan solo unos meses después de que hubiera tenido lugar la Marcha Verde y España hubiera abandonado al Sáhara a su suerte", cf. N. de Haro García, “Arte y disidencias en España, 1969-1979”, Arte y parte, febrero-marzo 2016, 121, p. 80.

69 Hay que aclarar que en ese momento el referente para LFL era la práctica del happening, que conocían a través de publicaciones internacionales como Art Forum, no las experiencias perfomativas. 


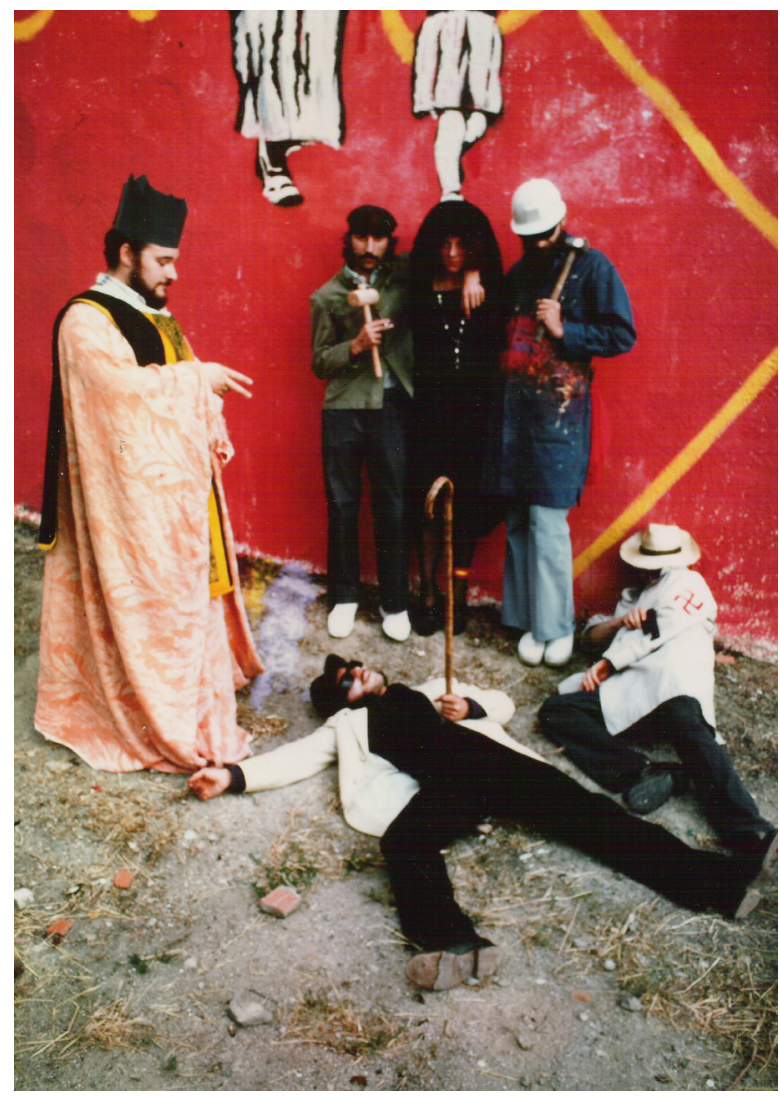

Figura 7. Acción de La Familia Lavapiés en las fiestas del barrio de Portugalete, junio de 1976.

\section{Final de partida}

En un texto retrospectivo escrito en 1977, apenas un año después de la disolución de LFL, Félix de la Torre hacía una breve descripción y balance de la trayectoria del grupo. Las aspiraciones que el colectivo había depositado en la incorporación de la actividad artística al movimiento revolucionario fueron frustradas por la resolución del ciclo político que siguió a la muerte de Franco. Pese a destacar las aportaciones que el marxismo, como ideología común a sus miembros, había proveído a las discusiones internas, reconocía que la autocrítica no siempre había estado a la altura de las ambiciones compartidas. Presagiando tal vez el olvido historiográfico que afectaría durante largas décadas a este tipo de prácticas, De la Torre declaraba que "alguna vez cuando se escriba la historia de la revolución española habrá que contar todo el rico caudal de experiencias que todos los grupos marxistas españoles marginados del PCE han aportado a la causa de la cultura"70. Sin embargo, los problemas presentados por la articulación entre la militancia política de clase y la defensa del trabajo cultural, solventada por arriba por el PCE mediante la consigna de unión entre am-

$\overline{70} \quad$ F. de la Torre Fajardo, "LFL. Una experiencia de arte popular”, op. cit., p. 2. 
bas fuerzas, apenas habían encontrado elaboración teórica en el seno de los debates sostenidos al interior de organizaciones como el PCE (m-1). A tres años vista, De la Torre evaluaba en estos términos las conclusiones "Sobre literatura y arte" extraídas del I Congreso del PCE (m-1), celebrado en la primavera de 1973 en un lugar próximo a Varese (Italia) ${ }^{71}$ :

La falta de investigación concreta de la situación española, el continuo repetir lugares comunes, el tono apocalíptico y dogmático invalidan la mayor parte de los análisis, llegando en ocasiones al planteamiento de enunciados claramente reaccionarios y estúpidos como denunciar el arte abstracto como revisionismo cultural; y deja sentir sobre todo el profundo desconocimiento de la problemática concreta, humana, profesional y creativa de aquellos a los que iba dirigido el escrito"72.

La ortodoxia teórica se inscribía en las rugosidades, miedos y afectos de una vida política y artística en clandestinidad que, pese a los intentos de fuga, no podía sustraerse a los efectos disciplinarios de la dictadura y la militancia. Por si fuera poco, los espacios de libertad que se abrieron en medio de esa coyuntura fueron obturados por la coartada cultural del cambio democrático, que tirando de manera interesada al niño junto al agua de la bañera condenó como parte de una misma cultura política el deseo de ruptura y la marcialidad ideológica. La estigmatización estética del radicalismo de izquierdas y del dogmatismo apodíctico ha sido funcional a aquella clausura institucional del campo artístico que, según Darío Corbeira, hace que "el tejido del arte [fuera en aquella época], por paradójico que pueda parecer, mucho más abierto y permeable a iniciativas nuevas de lo que es ahora"73. La disolución de LFL coincidió con el inicio de la recomposición del mapa político de la Transición, momento que aglutinó los esfuerzos de un sector de los militantes de la izquierda radical en la candidatura del FUT (Frente por la Unidad de los Trabajadores) para las elecciones legislativas de junio de $1977^{74}$. Jesús Marchante, militante de la LCR, diseñó para la campaña un collage fototextual inspirado en las vanguardias soviéticas, descartado por la coalición por temor a que sus resonancias militaristas justificaran su prohibición judicial. A renglón seguido, con motivo de un acto en el campo de fútbol del Pozo del Tío Raimundo, Paco Gámez, ex-miembro de LFL, elaboró otro cartel en el que Marx aparecía bailando con un travesti la música que, al fondo, interpretaba una orquesta popular (Fig. 8). Pese al fracaso electoral del FUT y al efecto social perdurable de la Cultura de la Transición -o, tal vez, justamente por ellos-, esa imagen a un tiempo alegre, melancólica y espectral quizás contenga aún esquirlas de la política radical por venir.

\footnotetext{
71 Sobre la organización del congreso, cf. Ricardo Gualino, FRAP. Una temporada en España. Madrid, Amargord, 2010, pp. 239 y ss.

72 F. de la Torre Fajardo, "LFL. Una experiencia de arte popular", op. cit., pp. 4-5.

73 D. Corbeira, "Arte y militancia en (la) transición”, op. cit., p. 86.

74 El FUT estaba integrado por la LCR, Acción Comunista (AC), la Organización de Izquierda Comunista (OIC) y el Partido Obrero de Unificación Marxista (POUM).
} 


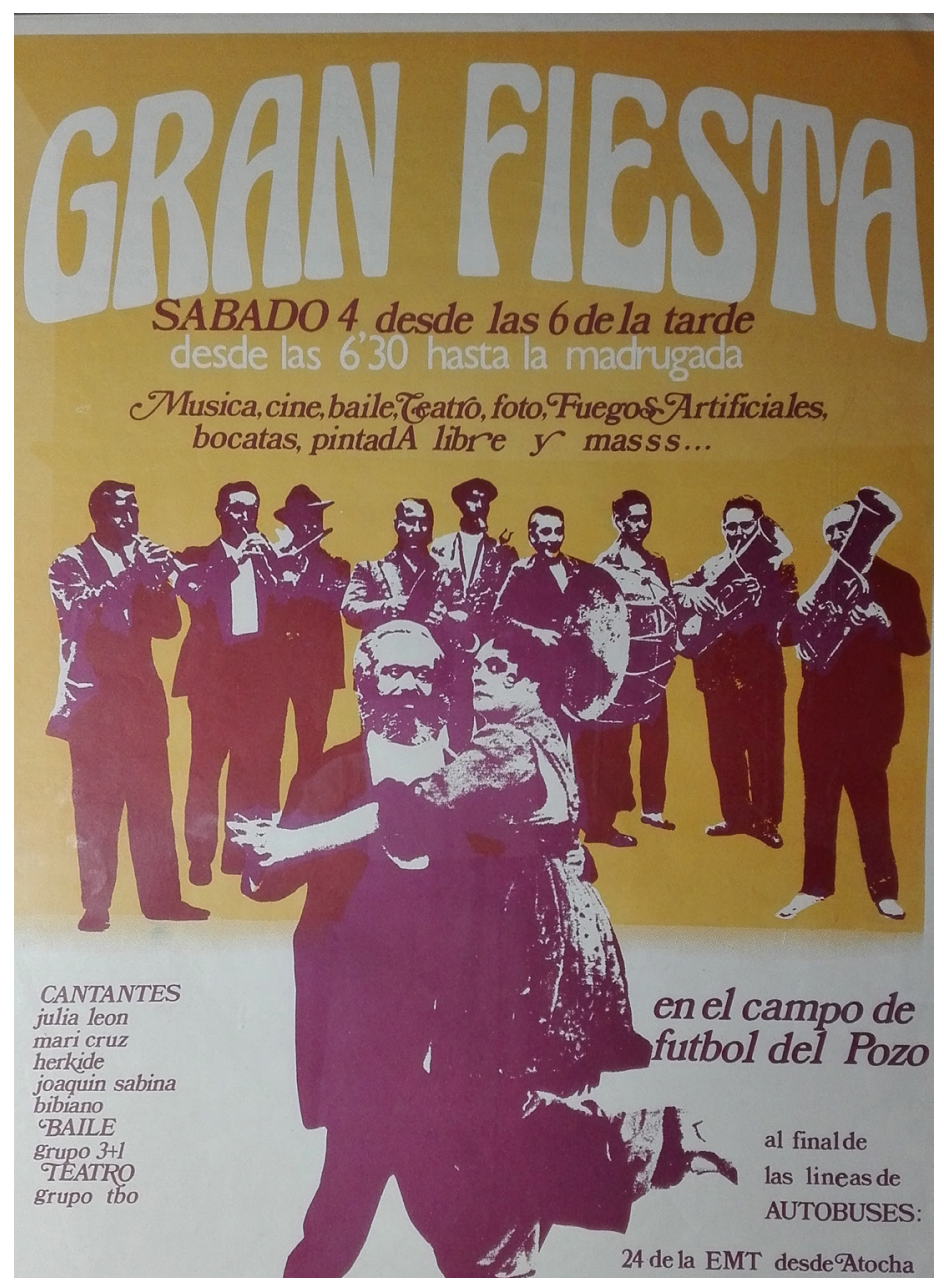

Figura 8. "Gran Fiesta", cartel diseñado por Paco Gámez para un acto de la candidatura del Frente por la Unidad de los Trabajadores en las elecciones legislativas de junio de 1977. 